\title{
Do Nonsteroidal Anti-Inflammatory Drugs Affect Bone Healing? A Critical Analysis
}

\author{
Ippokratis Pountos, ${ }^{1}$ Theodora Georgouli, ${ }^{1}$ Giorgio M. Calori, ${ }^{2}$ and Peter V. Giannoudis ${ }^{1,3}$ \\ ${ }^{1}$ Academic Department of Trauma \& Orthopaedics, School of Medicine, University of Leeds, Leeds LS1 3EX, UK \\ ${ }^{2}$ Academic Department of Trauma \& Orthopaedics, School of Medicine, University of Milan, 20122 Milano, Italy \\ ${ }^{3}$ Academic Unit, Department of Trauma and Orthopaedics, Clarendon Wing, Leeds Teaching Hospitals NHS Trust, \\ Great George Street, Leeds LS1 3EX, UK \\ Correspondence should be addressed to Peter V. Giannoudis, pgiannoudi@aol.com
}

Received 18 September 2011; Accepted 18 October 2011

Academic Editors: A. Ndreu and A. Sihoe

Copyright ( $) 2012$ Ippokratis Pountos et al. This is an open access article distributed under the Creative Commons Attribution License, which permits unrestricted use, distribution, and reproduction in any medium, provided the original work is properly cited.

\begin{abstract}
Nonsteroidal anti-inflammatory drugs (NSAIDs) play an essential part in our approach to control pain in the posttraumatic setting. Over the last decades, several studies suggested that NSAIDs interfere with bone healing while others contradict these findings. Although their analgesic potency is well proven, clinicians remain puzzled over the potential safety issues. We have systematically reviewed the available literature, analyzing and presenting the available in vitro animal and clinical studies on this field. Our comprehensive review reveals the great diversity of the presented data in all groups of studies. Animal and in vitro studies present so conflicting data that even studies with identical parameters have opposing results. Basic science research defining the exact mechanism with which NSAIDs could interfere with bone cells and also the conduction of well-randomized prospective clinical trials are warranted. In the absence of robust clinical or scientific evidence, clinicians should treat NSAIDs as a risk factor for bone healing impairment, and their administration should be avoided in high-risk patients.
\end{abstract}

\section{Introduction}

1.1. Bone Healing. Bone healing is one of the most complex cascades of events aiming to the repair of fractured bone without the formation of scar tissue [1]. In this physiological process, several cell types participate along with signal pathways and alternations in the biochemical profile of the local area. Bone healing can be either primary (direct) or secondary (indirect), $[1,2]$ with the majority of fractures heal indirectly, that is, a process subdivided in several stages [1]. The indirect fracture healing begins immediately after fracture occurrence with the disruption of local blood supply, hypoxia, and the formation of a hematoma, (Figure 1) [1]. Cytokines and growth factors are released both locally and systemically and induce a mitogenic and osteogenic effect on the osteoprogenitor cells [3-5]. The formation of new blood vessels, in association with further growth factor and prostaglandin production, promotes differentiation of mesenchymal stem cells (MSCs) toward chondrogenic or osteogenic lineages, forming initially woven bone and in turn, the hard callus $[3,6-8]$. Finally, this process is followed by an extended period of remodeling characterized by resorption and new bone formation, resulting in the restoration of mechanical strength and stability [8].

1.2. Factors Affecting Bone Healing. The outcome of bone healing can be affected by a diversity of local and systemic factors with varying degrees of affection including fracture gap and comminution, disturbances of blood flow, degree of soft tissue damage $[9,10]$, insufficient mechanical stability, [10-13], poor nutritional state, age, and smoking [14, 15]. Another important factor that can interfere with the body's ability to heal a fracture is the administration of several pharmacological agents [15]. Steroids, chemotherapy drugs, and some classes of antibiotics have been reported to exert a negative effect on bone healing $[15,16]$. In addition, NSAIDs that are one of the most commonly prescribed drugs for pain relief and inflammation to date have also been found to delay union and to inhibit fracture healing [15]. 

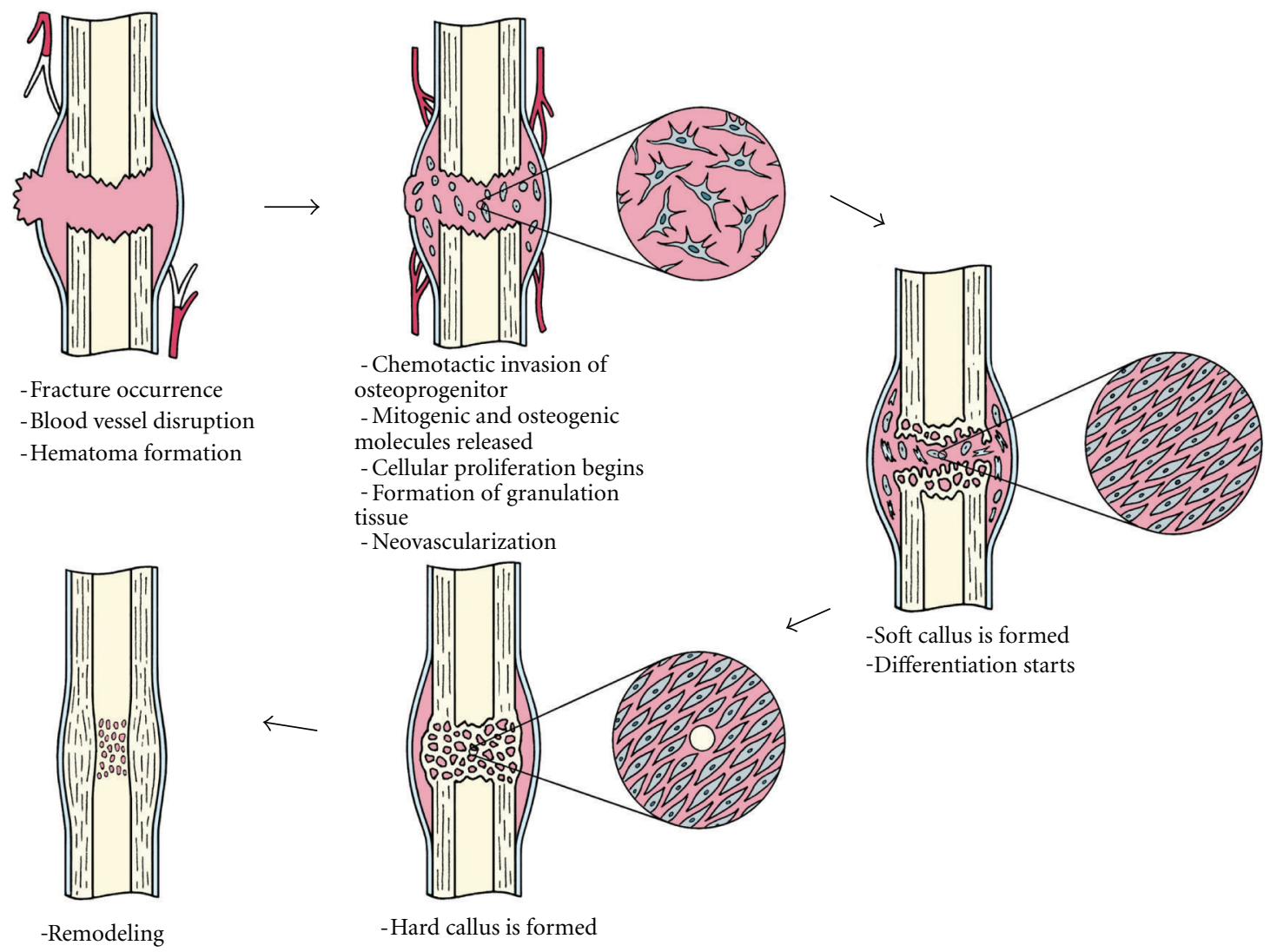

Figure 1: The fracture healing cascade.

1.3. NSAIDs Physiology. Nonsteroidal anti-Inflammatory drugs (NSAIDs) have their origin in the extracts of salicylatecontaining plants initially described in ancient Roman and Greek literature, with the willow tree extract to be renowned for their antipyretic, analgesic, and anti-inflammatory properties [17]. Their mode of action remained unknown till the 1970s when Sir John Vane demonstrated the inhibition of the enzymatic production of prostaglandins by NSAIDs [5].

During the biosynthesis of prostaglandins, cyclo-oxygenase (COX or prostaglandin $\mathrm{H}$ synthease) catalyses the conversion of arachidonic acid to the prostaglandin endoperoxidases $\mathrm{PGG}_{2}$ and then $\mathrm{PGH}_{2}[18,19]$. $\mathrm{PGH}_{2}$ is the precursor for the biological active prostaglandins and thromboxanes. $\mathrm{PGH}_{2}$ is then isomerized into various prostanoids such us thromboxane $\mathrm{A}_{2}\left(\mathrm{TXA}_{2}\right)$, prostacyclin $\left(\mathrm{PGI}_{2}\right), \mathrm{PGD}_{2}, \mathrm{PGE}_{2}$, and $\mathrm{PGF}_{2 \mathrm{a}}[18,19]$.

However, COX-1 is constitutively expressed in the most of cells and is involved in physiological processes. In the gastrointestinal tract $(\mathrm{GI})$, prostacyclin and $\mathrm{PGE}_{2}$ exert a protective effect by reducing acid secretion, vasodilatation of blood vessels of gastric mucosa, and stimulation of production of mucus which acts as a barrier [20]. In the kidneys, prostaglandins play a key role in regulating blood flow and enhancing organ perfusion [20]. COX-1 expression is also found in faetal and amniotic cells, uterine epithelium in early pregnancy, and central nervous system, and it is thought to exert complex integrative functions [21].
COX-2, on the other hand, is considered to be induced by inflammation and by the presence of proinflammatory cytokines and mitogens [22]. It has been suggested that the anti-inflammatory action of NSAIDs is due to the inhibition of COX-2, whereas COX-1 inhibition is associated to unwanted effects related to interference of the regulatory and protective mechanisms [22, 23]. Recent studies, however, have indicated that COX-2 is also constitutively expressed in the brain, and in particular, in the hippocampus and cortical glutaminergic neurons as well as the kidneys, uterus, and prostate $[24,25]$. Similarly, COX-1, despite its constitutively expression, has been shown to participate in inflammation (e.g., lipopolysaccharide-induced inflammation) where it might be inducible [26].

1.4. Prostaglandins during Fracture Healing. Prostaglandins (PGs) are autocrine and paracrine lipid mediators produced by several cell types capable of mediating either a stimulatory or resoptive role depending on the physiological or pathological conditions [27]. Administration of prostaglandins in animal models has shown to increase cortical and trabecular mass and cause hyperostosis in infants [28, 29]. Similarly, local administration of PGs in rat long bones had stimulatory properties suggesting direct effect on bone by inducing osteogenesis [30]. At a cellular level, PGs have a direct effect on osteoclasts leading to increased bone resorption by a mitogenic effect and increasing their functional activity [31]. 
On the other hand, PGs can exert an anabolic effect on the bone by increasing the multiplication and differentiation of osteoblasts [32]. One could claim that PGs safeguard the balance between bone resorption and bone formation [33].

Following a fracture, local release of PGs occurs early as a result of the acute aseptic inflammatory response [34]. COX-2 plays a critical role in this phase and its induction in osteoblasts is essential for bone healing [35]. In COX-2 null mice, fracture healing was found impaired characterized by reduced bone formation and persistence of mesenchyme and cartilage [36]. In the same study, COX-1 knockout animal was found to have the same healing potential to that of the normal wild type [36]. COX-2 activation therefore is a local regulator of cellular response within bone and responsible for the production of PGs [37]. It is not yet clear what the exact mechanism of PGs on bone cells is; however, it was found that PGE2 regulates BMP-2, BMP7, and RANKL expression [38-40], and it can increase cell numbers through suppression of apoptosis without direct effect on proliferation $[41,42]$. PGs exert this range of action through a variety of receptors expressed. These receptors belong to the G-protein-coupled receptor family and are the EP1, EP2, EP3, and EP4 subtypes [40]. Although the role of each receptor is not fully explored, studies suggest that the PGE2 binding to EP4 can stimulate osteoclastogenesis and osteoblastic differentiation, and animal models lacking the EP2 and EP4 receptors had defects in bone metabolism [43]. On the contrary, EP1 null mice found to have accelerated fracture repair and MSCs isolated from their bone marrow had higher osteoblast differentiation capacity and accelerated bone nodule formation and mineralization in vitro [44].

1.5. NSAIDs and Analgesia. In acute pain after fracture or during the postoperative period after fracture fixation, NSAIDs play an important role due to their pronounced analgesic potency, anti-inflammatory effects, and lesser side effects compared to opioids [7, 45]. However, studies comparing opiates and NSAIDs have shown that NSAIDs are at least as effective as opiates with some studies suggesting that NSAIDs can achieve greater reductions in pain scores [4652]. For acute pain, it has been suggested that NSAIDs should be used as the first line of treatment in pain therapy and recommend that opioids should be added only if pain is not controlled adequately with NSAIDs alone [50]. Furthermore, the use of NSAIDs instead of narcotic analgesics avoids significant side effects like respiratory depression, sedation, and cognitive effects [53]. For the postoperative patients, this can be translated with decreased hospital stay, allowing early mobilization and weight bearing $[15,46,51,52]$.

While there are clear benefits supporting the administration of NSAID's as pain relief agents following fractures, their wide-spread use has been challenged due to their reported negative impact on the bone repair processes $[47,51,52]$. Do NSAIDs inhibit the healing of fractures? Can they safely be administered?If so, at what time point and for how long? In order to provide replies to the above queries, we undertook a comprehensive review of the literature.

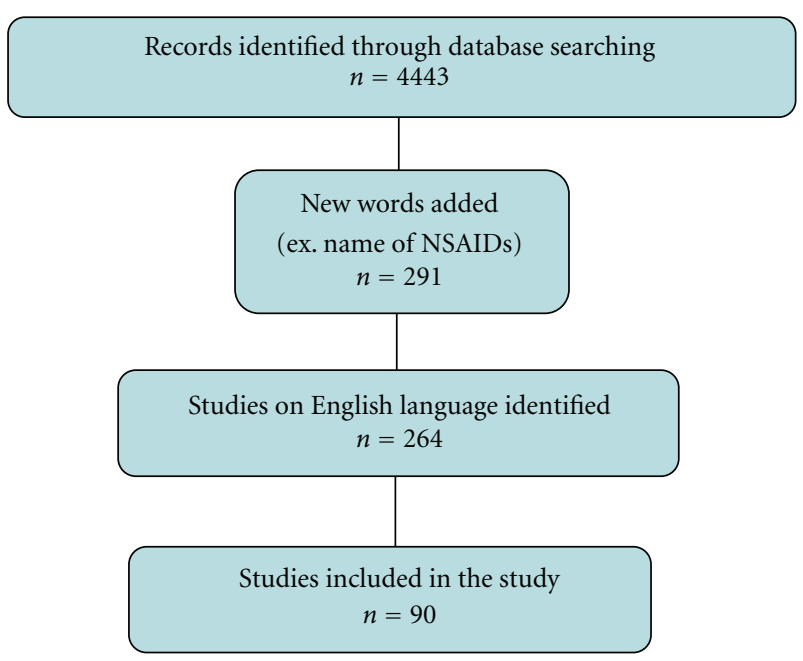

FIGURE 2: Flow chart diagram of included studies.

\section{Materials and Methods}

We searched available literature through PubMed, OVID, and EMbase with general keywords including "mesenchymal stem cells (MSC's)," "Bone healing," and "Bone marrowderived stem cells" both isolated or in combination with specific words including generic words like "NSAIDs" or specific names of NSAID's from January 1980 to January 2011. For paper selection, the initial inclusion criteria were studies publishing results on the effect of NSAIDs on bone healing in vivo both in humans and animal models, and also in-vitro studies on the effect of these agents on osteoprogenitor cells. Exclusion criteria included publications in languages other than English or studies with unclear methodology [54, 55]. The papers describing the effect of NSAIDs on bone healing were reviewed and are presented below.

\section{Results}

Out of 4443 papers that were initially isolated, 90 meet the inclusion criteria (Figure 2) [56-145]. Studies selected were grouped as experimental (in vivo or in vitro) or clinical as described below.

3.1. In-Vitro Models. We identified 18 in-vitro studies analyzing the effect of NSAIDs on osteoblasts and MSCs ability to proliferate and differentiate toward osteogenic lineages, (Table 1) [56-73]. An early study, byTörnkvist et al., using mesenchymal limb-bud cells reported no effect on osteogenesis and chondrogenesis by indomethacin [56]. However, the latter studies presented a diversity of results. The proliferation potential of osteogenic cells was found inhibited, and the higher the concentration, the more potent the antiproliferative effect was $[57,58,60,68,71]$. Interestingly, replenishment of PGE-1, PGE-2 and PGF2a did not reverse this negative effect $[64,68]$. Other studies showed no effect on low concentration and reported a negative effect at higher ones $[63,67,69,72,73]$. 
TABLE 1: In-Vitro Studies BM: Bone marrow, TB: Trabecular Bone.

\begin{tabular}{|c|c|c|c|}
\hline Year/Study & Model used & Drug & Outcome \\
\hline $\begin{array}{l}\text { Törnkvist et al., } \\
1984[56]\end{array}$ & $\begin{array}{l}\text { Chicken mesenchymal } \\
\text { limb-bud cells }\end{array}$ & Indomethacin $(25-100 \mu \mathrm{M})$ & (i) No effect on osteogenesis and chondrogenesis \\
\hline Ho et al., 1999 [57] & $\begin{array}{l}\text { Osteoblasts derived from } \\
\text { fetal rat calvaria }\end{array}$ & $\begin{array}{c}\text { Ketorolac }(0.1-1000 \mu \mathrm{M}) \\
\text { Indomethacin }(0.01-100 \mu \mathrm{M})\end{array}$ & $\begin{array}{l}\text { (i) All concentration of Ketorolac inhibited } \\
\text { proliferation at } 24 \text { hours } \\
\text { (ii) } 0.1 \mu \mathrm{M} \text { of indomethacin or higher inhibited } \\
\text { proliferation } \\
\text { (iii) A dose dependant increase of ALP was found } \\
\text { for concentration between } 0.1-100 \mu \mathrm{M} \text { of Ketorolac } \\
\text { (iv) Both NSAIDs stimulated collagen type I } \\
\text { synthesis }\end{array}$ \\
\hline $\begin{array}{l}\text { Evans and Butcher, } \\
2004[58]\end{array}$ & $\begin{array}{l}\text { Human trabecular bone } \\
\text { osteoblasts }\end{array}$ & Indomethacin $(0.003-0.3 \mu \mathrm{M} / \mathrm{L})$ & $\begin{array}{l}\text { (i) Inhibition of proliferation and increase in } \\
\text { collagen synthesis and ALP in a dose dependant } \\
\text { manner }\end{array}$ \\
\hline $\begin{array}{l}\text { Wang et al., } 2004 \\
\text { [59] }\end{array}$ & $\begin{array}{l}\text { MG63 human } \\
\text { osteoblasts }\end{array}$ & Celecoxib $(1-120 \mu \mathrm{M})$ & $\begin{array}{l}\text { (i) Dose dependant decrease of cellular } \\
\text { proliferation and stimulation of } \mathrm{Ca}^{++} \text {production }\end{array}$ \\
\hline $\begin{array}{l}\text { Chang et al., } 2005 \\
{[60]}\end{array}$ & $\begin{array}{l}\text { Osteoblasts derived from } \\
\text { fetal rat calvaria }\end{array}$ & $\begin{array}{l}\text { Diclofenac, piroxicam, } \\
\text { indomethacin Ketorolac } \\
\qquad(0.001-0.1 \mu \mathrm{M})\end{array}$ & $\begin{array}{l}\text { (i) All NSAIDs resulted in cell cycle arrest and cell } \\
\text { death } \\
\text { (ii) Piroxicam had the least effect to produce } \\
\text { osteoblastic dysfunction }\end{array}$ \\
\hline
\end{tabular}

\begin{tabular}{lcc}
\hline $\begin{array}{l}\text { Wang et al., 2006 } \\
{[61]}\end{array}$ & BM-derived Rat MSCs & Aspirin 1, 5, 10 mmol/L \\
\hline $\begin{array}{l}\text { Wiontzek et al., } \\
2006 \text { [62] }\end{array}$ & $\begin{array}{c}\text { MG63 human } \\
\text { osteoblasts }\end{array}$ & Celecoxib $(10 \mu \mathrm{M})$ \\
\hline $\begin{array}{l}\text { Wolfesberger et al., } \\
2006 \text { [63] }\end{array}$ & $\begin{array}{c}\text { Canine Osteosarcoma } \\
\text { cell line }\end{array}$ & Meloxicam $(1-200 \mu \mathrm{g} / \mathrm{mL})$ \\
\hline $\begin{array}{l}\text { Chang et al., 2007 } \\
{[64]}\end{array}$ & $\begin{array}{c}\text { Human MSCs and } \\
\text { D1-cells (Mice) }\end{array}$ & $\begin{array}{c}\text { Indomethacin }(10,100 \mu \mathrm{M}), \\
\text { Celecoxib }(1,10 \mu \mathrm{M})\end{array}$
\end{tabular}

\begin{tabular}{lc}
\hline Kellinsalmi et al., & Indomethacin $(1,10,100 \mu \mathrm{M})$, \\
$2007[65]$ & Parecoxib $(1,10,100 \mu \mathrm{M})$, \\
& $\operatorname{NS398}(0.03,0.3,3 \mu \mathrm{M})$
\end{tabular}

\begin{tabular}{lcc}
\hline $\begin{array}{l}\text { Arpornmaeklong et } \\
\text { al., 2008 [66] }\end{array}$ & Mouse calvaria cell line & Indomethacin $(0.1 \mu \mathrm{M})$, \\
& MC3T3-E1 & Celecoxib $(1.5,3,9 \mu \mathrm{M})$
\end{tabular}

\begin{tabular}{lc}
\hline Abukawa et al., 2009 & Porcine BM progenitor \\
{$[67]$} & cells
\end{tabular}

Chang et al., 2009

[68]

Human osteoblasts

Indomethacin $(0.1-1 \mu \mathrm{M})$,

Ketorolac $(0.1-1 \mu \mathrm{M})$,

Piroxicam $(0.1-1 \mu \mathrm{M})$,

Diclofenac $(0.1-1 \mu \mathrm{M})$,

Celecoxib $(1-10 \mu \mathrm{M})$

\begin{tabular}{|c|c|c|}
\hline $\begin{array}{l}\text { Kolar et al., } 2009 \\
{[69]}\end{array}$ & $\begin{array}{l}\text { MG63 human } \\
\text { osteoblasts }\end{array}$ & Celecoxib $(2,10,50 \mu \mathrm{M})$ \\
\hline
\end{tabular}

(i) Inhibition of MSCs proliferation

(i) No effect on $\mathrm{Ca}^{++}$production, COX-2 expression, ALP and osteocalcin

(i) Marked untiproliferative effect for concentrations over 100 while lower concentrations resulted in an increase of cell numbers

(i) Inhibition of proliferation for both NSAIDs but no significant cytotoxic effect

(ii) Replenishment of PGE-1, PGE-2 and PGF2a did not reverse this negative effect

(i) All studied NSAIDs inhibited osteoblastic and osteoclastic differentiation

(ii) Significant increase of adipocytes suggesting diversion to adipogenesis instead of osteogenesis

(i) Inhibition of growth with both NSAIDs than Celecoxib

(i) $0.1 \mathrm{mmol} / \mathrm{L}$ had no effect on proliferation, ALP, bone matrix mineralization while inhibition found for the higher studied concentrations

(i) Inhibition of proliferation occurred with all studied NSAIDs

(ii) Replenishment of PGE-1, PGE-2 and PGF2a did not reverse this negative effect

(i) Marginal effect with the concentrations of 2 and $10 \mu \mathrm{M}$ but $50 \mu \mathrm{M}$ reduced cell viability and OPG secretion and stimulated oxygen consumption and GLUT-1 expression

(i) No effect on ALP and Calcium content in absence of Interleukin $1 \beta$ while in its presence ALP and Calcium was reduced only with the highest studied concentration (ii) Indomethacin had a higher inhibitory effect
Yoon et al., 2010

[70]
Human BM MSCs
Celecoxib $(10,20,40 \mu \mathrm{M})$, Naproxen $(100,200,300 \mu \mathrm{M})$ 
TABle 1: Continued.

\begin{tabular}{|c|c|c|c|}
\hline Year/Study & Model used & Drug & Outcome \\
\hline $\begin{array}{l}\text { Guez et al., } 2011 \\
{[71]}\end{array}$ & $\begin{array}{l}\text { Human MG-63 } \\
\text { Osteosarcoma Cell }\end{array}$ & $\begin{array}{l}\text { Indomethacin }(1-10 \mu \mathrm{M}) \\
\text { Nimesulide }(1-10 \mu \mathrm{M}) \\
\text { Diclofenac }(1-10 \mu \mathrm{M})\end{array}$ & $\begin{array}{l}\text { (i) All NSAIDs had an inhibiting effect on } \\
\text { osteoblastic proliferation and significant effects on } \\
\text { the antigenic profile } \\
\text { (ii) No treatment altered osteocalcin synthesis }\end{array}$ \\
\hline $\begin{array}{l}\text { Müller et al., } 2011 \\
\text { [72] }\end{array}$ & Equine BM MSCs & $\begin{array}{l}\text { Flunixin }(10-1000 \mu \mathrm{M}) \\
\text { phenylbutazone }(10-1000 \mu \mathrm{M}) \\
\text { Meloxicam }(0.01-200 \mu \mathrm{M}) \\
\text { Celecoxib }(0.01-200 \mu \mathrm{M})\end{array}$ & $\begin{array}{l}\text { (i) Low NSAIDs concentrations had positive effect } \\
\text { on proliferation while the higher ones inhibited } \\
\text { proliferation } \\
\text { (ii) Adipogenic and chondrogenic differentiation } \\
\text { was found unaltered however osteogenesis was } \\
\text { significantly disrupted }\end{array}$ \\
\hline $\begin{array}{l}\text { Pountos et al., } 2011 \\
\text { [73] }\end{array}$ & $\begin{array}{c}\text { BM and TB derived } \\
\text { MSCs }\end{array}$ & $\begin{array}{l}\text { Diclofenac, Ketorolac, Parecoxib, } \\
\text { Ketoprofen, Piroxicam, } \\
\text { Meloxicam and Lornoxicam } \\
\text { (all } 0.001 \text { to } 100 \mu \mathrm{g} / \mathrm{mL} \text { ) }\end{array}$ & $\begin{array}{l}\text { (i) No effect on MSCs proliferation when cellular } \\
\text { medium was supplemented with expected plasma } \\
\text { concentrations } \\
\text { (ii) Negative effect encountered when high } \\
\text { concentrations used (over } 100 \mu \mathrm{g} / \mathrm{mL} \text { ) } \\
\text { (iii) NSAIDs in plasma concentrations had no } \\
\text { effect on osteogenesis } \\
\text { (iv) Chondrogenesis was found inhibited by } \\
\text { NSAIDs }\end{array}$ \\
\hline
\end{tabular}

The osteogenic potential of the studied cells, measured by the levels of ALP activity and calcium production, was either found increased or unaffected in the majority of the studies [56-59, 62, 73]. NSAIDs also reported to stimulate collagen synthesis $[57,58]$. On the contrary, other researchers failed to reproduce this result showing disruption of osteogenesis $[65,72]$. Kellinsalmi et al. reported that indomethacin, parecoxib, and NS398 inhibited osteoblastic differentiation of human MSCs and found a significant increase of adipocytes suggesting diversion to adipogenesis instead of osteogenesis [65].

In terms of chondrogenesis, limited studies exist which either present no effect [72] or a negative effect in expected concentrations after administration [73]. In an attempt to explain this wide diversity of results, it was apparent that cells were isolated from a variety of species and sites [5658, 66, 68, 69, 72, 73]. However, we could not find any association between them, and no association was apparent between different NSAIDs or even selectivity toward the COX-1 or COX-2 enzyme to explain these results.

3.2. Animal Models. A large volume of work has been undertaken over the last 4 decades using experimental fracture animal models. The majority of these studies were centred over rodents or rabbits, and as with the in-vitro studies, great diversity and controversial results have been presented in the 54 studies identified (Table 2) [74-127]. A proportion of these studies suggest that NSAIDs adversely affect the bone physiology by delaying bone healing and callus formation, impairing bending stiffness and the bones' mechanical properties leading to an increased rate of nonunions [74105]. Some authors have even compared NSAIDs effect on fracture healing with that of other pharmacological agents like steroids [89, 91]. Høgevold et al. presented that short-term administration of indomethacin inhibits fracture healing while this was not the case with short-term administration of methylprednisolone [89].

On the other hand, several studies failed to reproduce this effect suggesting that NSAIDs have no effect of fracture healing [110-125]. The results were so controversial that different researchers with identical animal fracture models, same drugs, and same doses presented opposite outcomes $[122,127]$. Analysing these studies further, we could not identify any association among the class or potency of the studied NSAIDs to inhibit the COX-1 or COX-2 enzyme, the dose, or the timing. In terms of timing, although some authors suggest that short-term administration after fracture could be safe, others contradict this finding suggesting that NSAID administration is safe only if it is initiated a few weeks after fracture $[78,85,98,101,105,106,108,126]$. A link, however, can exist between the size of the animals. The vast majority of the animal models involved rodents or rabbits. There are two studies that involved dogs and goats whose results showed no inhibition of bone healing or bone ingrowth suggesting that the type or size of the animal model used might be an explanation for the differences seen in the results presented $[113,117]$.

3.3. Clinical Studies. There are only a few retrospective human studies and even fewer prospective randomized trials studying the effect of NSAIDs after fracture or spinal fusion, (Tables 3 and 4) [128-145]. In a double-blinded randomized control trial, Adolphson et al. found that piroxicam had no effect on the healing potential of 42 postmenopausal women with displaced Colles' fractures [137]. Similar findings were reported by Davis and Ackroyd who studied the effect of fluriprophen on Colles' fracture healing potential [136]. In cementless hip arthroplasty, indomethacin was found to have no effect on the prosthetic loosening. No effect was also reported in a randomized, controlled, and blinded study 
TABle 2: Animal studies: agents and model used in relation to the presented effect.

Impaired bone healing

(1) Aspirin [84]

(2) Celecoxib [101, 102]

(3) Diclofenac [97-99]

(4) Etodolac [104, 105]

(5) Ibuprofen [88, 94-96, 127]

(6) Indomethacin [78-91, 119, 127]

(7) Ketoprofen [77]

(8) Ketorolac [74-76, 107]

(9) Meloxicam [85, 103]

(10) Naproxen [92, 93]

(11) Parecoxib [74]

(12) Rofecoxib [92, 94, 95, 108, 109]

(13) Tenoxicam $[99,100]$

(14) Valdecoxib [107]

No effect

(1) Celecoxib [80, 111, 119, 120]

(2) Diclofenac [123]

(3) Etoricoxib [110]

(4) Ibuprofen [111, 121, 122]

(5) Indomethacin [81, 111, 114-118]

(6) Ketoprofen [112, 113]

(7) Ketorolac [110, 111]

(8) Meloxicam [113]

(9) Nimesulid [124]

(10) Rofecoxib [111, 123, 125]

Short term has no effect

(1) Diclofenac $[98,106]$

(2) Ketoprofen [126]

(3) Ketorolac [78]

(4) Parecoxib [106]

(5) Rofecoxib [85, 108]

(6) Valdecoxib [106]

Model used

(i) Rats

$[74,77,78,80,81,83,84,89-91,93,94,97,98,100$ -

$107,110,114,116,118,121-124,126]$

(ii) Mouse $[109,111,120]$

(iii) Rabbit

[75, 76, 79, 82, 85-88, 92, 95, 96, 99, 108, 112, 115, 119, 125]

(iv) Dog [117]

(v) Goats [113]

by Sculean et al. who studied the effect of rofecoxib on the healing of intrabony periodontal defects [143]. On the contrary, four retrospective studies suggested that patients using NSAIDs after fracture had a higher incidence of nonunion compared to those that did not [140-142, 144]. Bhattacharyya et al., have suggested that patients receiving
NSAIDs within 90 days after fracture had a 3.7-fold risk for nonunion, while the risk for opioids users was 1.6 folds [144].

Detrimental effects in spinal fusion are presented by some authors, while others concluded that NSAIDs do not affect union. Park et al. found that the incidence of incomplete union or nonunion was much higher in patients taking ketorolac and the relative risk was approximately 6 times higher compared to that of the control group [131]. A more recent study by Lumawig et al. indicated that diclofenac sodium showed a dose-dependent inhibitory effect toward spinal fusion especially when used during the immediate postoperative period [134]. In addition, it was pointed out that patients who continued to take NSAIDs for more than 3 months postoperatively showed significantly lower fusion and success rates [128]. On the contrary, other studies failed to support these findings suggesting that NSAIDs do not affect union after spinal fusion [130, 133, 135].

\section{Discussion}

For many years, NSAIDs have played an essential part in our approach to control pain in the posttraumatic setting. However, several authors highlighted that NSAIDs could inhibit the bone healing process. The available data from animal studies have all evaluated the properties of newly formed bone in animals that NSAIDs were administered in different doses and durations. One could expect some uniformity in these results but on the contrary great diversity and conflicting results exist. It is of question how so many studies have failed to provide a clear message with regards to the effect and mode of action of NSAIDs on bone healing in animals. The differences reported were not only between species, dose, and duration of administration but also between identical parameters. For instance, $30 \mathrm{mg} / \mathrm{kg} /$ day of ibuprofen given orally in rats had no effect on femoral fracture by Huo et al. [122], but retardation of fracture healing with significant differences of mechanical and histological properties was reported by Altman et al. [127]. Many researchers have also chosen long-term administration of NSAIDs or high doses that is against the intended human therapies. For example, Leonelli et al. compared the effect of $30 \mathrm{mg} / \mathrm{kg} /$ day of Ibuprofen and $8 \mathrm{mg} / \mathrm{kg} /$ day of rofecoxib on the union potential of a closed femoral fracture in a rat model [94]. Their results showed nonunions in $64.7 \%$ of rofecoxib-treated rats and $17.6 \%$ of ibuprofen-treated rats but the dose of rofecoxib used was more than 10 times the dose given in humans for acute pain. It is also unclear whether this diversity of results is due to inter- or intraspecies differences, compensatory local and systemic factors, or even different pharmacokinetics of the drugs in the laboratory models compared to humans. It is possible that secondary factors influence the final result like the level of analgesia achieved by a specific dose and class of NSAID affecting the weight bearing status for some animals and thus to evolution of healing.

The extent of trauma and the comminution of the fractures produced in these experimental models, we believe, is another major factor that could explain the differences 
TABLE 3: The effect of NSAIDs on spinal fusion in humans.

\begin{tabular}{|c|c|c|c|}
\hline Study/Year & Design & NSAID used & Conclusions and recommendations \\
\hline $\begin{array}{l}\text { Deguchi et al., } 1998 \\
\text { [128] }\end{array}$ & $\begin{array}{l}\text { Retrospective review of } 73 \text { patients } \\
\text { undergoing primary or revision one or } \\
\text { two level lumbar fusion }\end{array}$ & Not specified & $\begin{array}{l}\text { (i) Patients who continued to take NSAIDs for } \\
\text { more than } 3 \text { months postoperatively showed } \\
\text { significantly lower fusion and success rates }\end{array}$ \\
\hline $\begin{array}{l}\text { Glassman et al., } 1998 \\
\text { [129] }\end{array}$ & $\begin{array}{l}\text { Retrospective review of } 288 \text { patients } \\
\text { undergoing posterior L4 to sacral } \\
\text { fusion }\end{array}$ & Ketorolac & $\begin{array}{l}\text { (i) High rate of nonunion in spinal fusion } \\
\text { (ii) Avoid NSAIDs in early postoperative period is } \\
\text { recommended }\end{array}$ \\
\hline $\begin{array}{l}\text { Vitale et al., } 2003 \\
{[130]}\end{array}$ & $\begin{array}{l}\text { Retrospective review of } 208 \text { children } \\
\text { undergoing scoliosis correction }\end{array}$ & Ketorolac & $\begin{array}{l}\text { (i) No significantly increase in complications, } \\
\text { including transfusion and reoperation }\end{array}$ \\
\hline Park et al., 2005 [131] & $\begin{array}{l}\text { Retrospective review of } 88 \text { consecutive } \\
\text { patients undergoing posterolateral } \\
\text { lumbar fusion }\end{array}$ & Ketorolac & $\begin{array}{l}\text { (i) The incidence of incomplete union or } \\
\text { nonunion was much higher in the ketorolac } \\
\text { group, and the relative risk was approximately } 6 \\
\text { times higher than control group }\end{array}$ \\
\hline $\begin{array}{l}\text { Pradhan et al., } 2008 \\
\text { [132] }\end{array}$ & $\begin{array}{l}\text { Retrospective review of } 405 \\
\text { consecutive patients undergoing one, } \\
\text { two or three level posterolateral } \\
\text { lumbar fusion }\end{array}$ & Ketorolac & $\begin{array}{l}\text { (i) The use of ketorolac limited to } 48 \text { hours after } \\
\text { surgery for adjunctive analgesia, has no } \\
\text { significant effect on ultimate fusion rates. }\end{array}$ \\
\hline $\begin{array}{l}\text { Sucato et al., } 2008 \\
{[133]}\end{array}$ & $\begin{array}{l}\text { Retrospective review of } 319 \text { patients } \\
\text { undergoing scoliosis correction }\end{array}$ & Ketorolac & $\begin{array}{l}\text { (i) Ketorolac does not increase the incidence of } \\
\text { developing a pseudoarthrosis when used as an } \\
\text { adjunct for postoperative analgesia }\end{array}$ \\
\hline $\begin{array}{l}\text { Lumawig et al., } 2009 \\
\text { [134] }\end{array}$ & $\begin{array}{l}\text { Retrospective review of } 273 \text { patients } \\
\text { undergoing one or two level posterior } \\
\text { lumbar fusion }\end{array}$ & Diclofenac & $\begin{array}{l}\text { (i) Diclofenac sodium showed a dose-dependent } \\
\text { inhibitory effect toward spinal fusion especially } \\
\text { when used during the immediate postoperative } \\
\text { period }\end{array}$ \\
\hline $\begin{array}{l}\text { Horn et al., } 2010 \\
{[135]}\end{array}$ & $\begin{array}{l}\text { Retrospective review of } 46 \text { pediatric } \\
\text { patients who undergone spinal fusions } \\
\text { for scoliosis }\end{array}$ & Ketorolac & $\begin{array}{l}\text { (i) No clinical or radiographic evidence of curve } \\
\text { progression, nonunion, or instrumentation } \\
\text { failure }\end{array}$ \\
\hline
\end{tabular}

between researchers. Differences in the fracture comminution, force used, soft tissue damage, and fracture stability achieved can all influence the final result. This argument can be further strengthened by the observations of Engebretsen et al., who reported that indomethacin exerted a negative effect in unstable fracture condition while in stable ones had no significant effect compared to controls [78]. This could also explain the high complication rates presented even for the control animal groups. Long et al., for instance, studied the effect of celecoxib and indomethacin on a rabbit model of spinal fusion [119]. Their results showed fusion rates of $64 \%$ in the control group, $45 \%$ for the celecoxib group, and $18 \%$ for the indomethacin group. Although a significant negative effect is presented with these two NSAIDs, a nonunion rate of $36 \%$ is high to be used as baseline. It is possible, for example, that NSAIDs interfere only in endochondral ossification, therefore, if the fracture is comminuted and highly unstable, NSAIDs might have a detrimental effect on the consolidation process, while in a more stable fracture, NSAIDs could be totally ineffective.

One positive association could be the fact that the majority of the animal studies involved small animals, that is, rodents and rabbits, while the available studies involving goats and dogs show no effect of bone ingrowth or healing $[113,117]$. This could be an important finding as marked interspecies differences with regard to bone composition, bone density, bone mechanical competence and bone cells exist and are more pronounced in small rodents while dogs approximate human bone properties the best [146]. On the other hand, NSAIDs pharmacokinetics could be significantly different between species and humans, and in fact studies analyzing NSAIDs kinetic parameters show significant differences $[147,148]$. Despite the above-mentioned limitations of animal models, further studies will be needed to strengthen these assumptions.

The in-vitro studies follow exactly the same pathway, being inconclusive and difficult to interpret. Some studies present a strong effect of NSAIDs on the potential of osteoprogenitor cells to proliferate and differentiate toward an osteogenic lineage while others refute it (Table 1). A determining factor could be the use of cells from a variety of species which include cells from rodents, chicken, horses, dogs, and pigs as well as human cells $[56,73]$. This diversity of cell sources could be crucial as cells from animals could react in a different fashion to the human cells and in fact according to our experience, animal MSCs exert different proliferation and differentiation rates compared to human cells. In terms of the human cells, some authors have used osteosarcoma cells which are pathologic cell type characterized by aggressive numerous atypical mitoses, and their properties are far different to that of MSCs [59, 62, 69, 71]. Differences could even exist between the same osteoprogenitor cells isolated from humans who suffer from a fracture compared to those who do not, as systemic signals are triggered forcing the cells to proliferate or differentiate toward a specific way as a result of the trauma stimulus sustained $[149,150]$. 
TABLE 4: Studies analyzing the effect of NSAIDs on bone healing in humans.

\begin{tabular}{|c|c|c|c|}
\hline Study/Year & Design & NSAID used & Conclusions and recommendations \\
\hline $\begin{array}{l}\text { Davis and Ackroyd, } \\
1988[136]\end{array}$ & $\begin{array}{l}\text { Prospective double-blinded } \\
\text { study of } 100 \text { patients with Colles' } \\
\text { fracture }\end{array}$ & $\begin{array}{l}\text { Fluriprophen } \\
\text { (50 mg TDS) }\end{array}$ & (i) No effect on Colles' fracture. \\
\hline $\begin{array}{l}\text { Adolphson et al., } 1993 \\
\text { [137] }\end{array}$ & $\begin{array}{l}\text { Randomized double-blinded } \\
\text { study on } 42 \text { postmenopausal } \\
\text { women with colles fracture }\end{array}$ & Piroxicam & $\begin{array}{l}\text { (i) No decrease of the rate of fracture healing } \\
\text { (ii) Patients receiving piroxicam had } \\
\text { significantly less pain } \\
\text { (iii) No difference in the rate of functional } \\
\text { recovery }\end{array}$ \\
\hline $\begin{array}{l}\text { Butcher and Marsh, } \\
1996[138]\end{array}$ & $\begin{array}{l}\text { Retrospective review of } 94 \\
\text { patients with tibial fracture }\end{array}$ & Not specified & $\begin{array}{l}\text { (i) Increase in the length of time to union by of } \\
7.6 \text { weeks }(P=0.0003) \text { ( } 16.7 \text { weeks versus } 24.3 \\
\text { weeks). }\end{array}$ \\
\hline $\begin{array}{l}\text { Wurnig et al., } 1999 \\
\text { [139] }\end{array}$ & $\begin{array}{l}80 \text { prospective patients receiving } \\
\text { indomethacin prophylaxis for } \\
\text { THR compared with } 82 \text { patients } \\
\text { without. }\end{array}$ & $\begin{array}{l}\text { Indomethacin } \\
\text { (Oral } 50 \mathrm{mg} \mathrm{BD})\end{array}$ & $\begin{array}{l}\text { (i) No effect on prosthetic loosening after } \\
\text { cementless hip arthroplasty }\end{array}$ \\
\hline $\begin{array}{l}\text { Giannoudis et al., } 2000 \\
{[140]}\end{array}$ & $\begin{array}{l}\text { Retrospective review of } 377 \\
\text { patients treated with IM nail }\end{array}$ & $\begin{array}{c}\text { Ibuprophen and } \\
\text { Diclofenac }\end{array}$ & $\begin{array}{l}\text { (i) Increased risk for nonunion in patients } \\
\text { receiving NSAIDs }\end{array}$ \\
\hline $\begin{array}{l}\text { Bhandari et al., } 2003 \\
{[141]}\end{array}$ & $\begin{array}{l}\text { Retrospective review of } 192 \text { tibial } \\
\text { shaft fractures }\end{array}$ & Not specified & $\begin{array}{l}\text { (i) Relative risk of } 2.02(P=0.035) \text { for patient } \\
\text { who take NSAIDs }\end{array}$ \\
\hline Burd et al., 2003 [142] & $\begin{array}{l}\text { Retrospective review of } 282 \text { with } \\
\text { acetabular fractures }\end{array}$ & Indomethacin & $\begin{array}{l}\text { (i) Patients receiving indomethacin had } \\
\text { increased risk for developing non-union }\end{array}$ \\
\hline $\begin{array}{l}\text { Sculean et al., } 2003 \\
{[143]}\end{array}$ & $\begin{array}{l}\text { Randomized blindied study on } \\
20 \text { patients with deep intrabony } \\
\text { defect }\end{array}$ & $\begin{array}{c}\text { Rofecoxib } \\
(25 \mathrm{mg} / \text { day for } 14 \text { days })\end{array}$ & $\begin{array}{l}\text { (i) No effect on the healing of intrabony } \\
\text { periodontal defects }\end{array}$ \\
\hline $\begin{array}{l}\text { Bhattacharyya et al., } \\
2005[144]\end{array}$ & $\begin{array}{l}\text { Retrospective review of } 9995 \\
\text { humeral shaft fractures treated } \\
\text { nonoperatively }\end{array}$ & Not specified & $\begin{array}{l}\text { (i) Exposure to nonselective NSAIDs in the } \\
\text { period } 61-90 \text { days after a humeral shaft fracture } \\
\text { was associated with nonunion }\end{array}$ \\
\hline $\begin{array}{l}\text { Meunier et al., } 2009 \\
{[145]}\end{array}$ & $\begin{array}{l}\text { Randomized study involving } 50 \\
\text { patients undergoing total knee } \\
\text { replacement }\end{array}$ & $\begin{array}{c}\text { Celecoxib } \\
(200 \mathrm{mg} \mathrm{BD})\end{array}$ & $\begin{array}{l}\text { (i) No differences in prosthesis migration, pain } \\
\text { scores, range of motion, and subjective outcome } \\
\text { were found after } 2 \text { years }\end{array}$ \\
\hline
\end{tabular}

It merits saying that NSAIDs can affect the osteoprogenitor cells by a pathway far different to that of the inhibition of COX-1 and COX-2 enzymes, therefore, differences in tissue culture parameters could influence the final result. This so-called "non-Cox effect" is unfortunately poorly understood. According to this theory, the NSAIDs properties related the protective effect against the tumors, cancer inhibition, and the prevention of metastasis as well as the prevention of other pathologies like Alzheimer's disease or cataract cannot be explained solely by the inhibition of prostaglandins, therefore, an alternative unrelated to COX enzymes inhibition pathway should exist to explain these results [17]. This theory can be strengthened by the studies of Chang et al., who presented that the replenishment of PGE1, PGE-2, and PGF2a did not reverse this negative effect on bone cells produced by the studied NSAIDs [64, 68].

This comprehensive review includes the data of 18 , mainly retrospective, clinical studies trying to enlighten this area of high interest [128-145]. Two early studies involved patients suffering from Colles' fracture reported no effect of NSAIDs on union rates $[136,137]$. It is of note, however, that nonunion after Colles' fracture is rare and only a few case reports exist [148]. There are a few case studies that tried to define an association between NSAIDs exposure and nonunion [140-142, 144]. Most of them report an increased incidence of nonunion among the patients that received NSAIDs. Although this can be true, many covariates that could influence this result like smoking, extent of trauma, comminution, patient demographics, and diabetes were not isolated. Unavailable bias of variable forms could exist in a large number of these studies. In a retrospective review of approximately 10,000 humeral shaft fractures treated nonoperatively, the authors reported increased incidence of nonunion among patients receiving NSAIDs [144]. However, opioids user had an increased risk as well. To our knowledge, we are not aware of any studies highlighting a similar effect. So, does this mean that NSAIDs increase the risk for a nonunion or that patients with unhealed fractures require significant amounts of analgesia for prolonged period of time? Another study showed that NSAIDs users had a relative risk of $2.02(P=0.035)$ for reoperation compared to nonusers [141]. Similar to the previous example, patients with complications requiring a second operation would have increased analgesic needs. In the same study, the risk for patients receiving antibiotics was $3.01(P=0.002)$. Although some antibiotics can interfere with the bone healing process [16], it looks more plausible that the extent of injury and/or a contaminated open fracture is the cause for this observation. 
These two examples highlight the difficulties faced by the researchers on these observational studies and the potential presence of bias.

In spinal fusion, the results presented are more uniform. Some studies suggest that NSAIDs have no effect on union rates, [130, 132-135] while some others showed a dosedependant inhibitory effect underlining that patients who continued to take NSAIDs for more than 3 months postoperatively showed significantly lower success rates [128]. Potential presence of bias can exist in these studies as well and it is unclear whether COX-2 selective NSAIDs do have an effect as the vast majority of these studies utilize ketorolac which is a high COX-1 inhibitor. It is worth mentioning that there are significant differences in the nonunion rates between long bones and spine. The nonunion in spinal fusion can be as high as 15\% [151]. Differences in structure, mechanical loading, and function of vertebrae also exist. This can result in different degrees of affection, if any, by NSAIDs.

The effect of NSAIDs on heterotopic ossification (HO) has being used as an argument against NSAIDs administration during fracture healing. HO is defined as the process by which marrow-containing boneis formed in soft tissues outside the skeleton $[152,153]$. NSAIDs have proven to have a strong effect on this process although the pathophysiology is not fully understood [15]. A Cochraine meta-analysis of 17 trials involving more than 1900 patients having hip joint replacemnet suggested that NSAID administration reduces HO by $59 \%$ [152]. Although this is true, HO should not be confused with bone healing as it is a pathologic condition in which a fully differentiated and comitted cell turns into bone. Contributing factors for the development of $\mathrm{HO}$ have been proposed to be the locally released BMPs, inflammation and PGE-2 production, hypercalcemia, hypoxia, abnormal nerve activities, immobilization, and disequilibrium of hormones $[153,154]$. HO does not follow the fracture healing cascade and significant differences of the local microenviroment characteristics exist as, for example, the mechanical loads that are applied on these tissues are minimal compared to those between the fragments of a broken bone. It is also possible that the fully committed cells switch from one type to another similar to what occurs in the transdifferentiation of MSCs [155].

NSAIDs, due to their ability to inhibit the production of prostaglandins, alleviate the intrinsic local inflammatory response, desensitizing the peripheral pain receptors. Although they are potent analgesics, some studies showed that they can inhibit bone healing, while some others disagreed with these findings. This has triggered a wide range of responses from the medical community, ranging from recommendation of cautious use to statements like "when fracture healing or spine fusion is desired, nonsteroidal antiinflammatory drugs should be avoided" [156]. The outcome is a widespread confusion with some centres having ignored these recommendations while others rely on narcotic analgesia for pain control even for nondisplaced fractures.

In the absence of robust scientific evidence concerning the use of NSAIDs after fracture, a definite statement regarding their use cannot be made. However, based on the available literature, some simple carefully derived recom- mendations can be issued. According to the authors' opinion, there is rather weak evidence to absolute contraindicate the use of NSAIDs in patients suffering from a fracture. NSAIDs administration should be considered as a risk factor for delayed fracture healing, at extreme as equal to smoking, corticosteroids, or diabetes. Clinicians could consider them as low-risk patients and for ashort period, probably not exceeding a week after fracture. The need of prospective well-controlled clinical trials is warranted. Patient selection and recruitment, the randomization of patients, and ways to overcome ethical issues are all crucial. In addition, defining the pathway by which NSAIDs could affect bone cells would be of paramount importance.

\section{Conclusion}

There is no robust clinical and/or scientific evidence to discard the use of NSAIDs in patients suffering from a fracture, but equal lack of evidence does not constitute proof of the absence of an effect. The majority of the available evidence is based on animal findings and these results should be interpreted with caution due to the differences in physiological mechanisms between humans and animals. The need of basic science research defining the exact mechanism that NSAIDs could interfere with bone cells and the conduction of wellrandomized prospective clinical trial are warranted. Till then, clinician should treat NSAIDs as a risk factor for bone healing impairment and should be avoided in high-risk patients.

\section{Conflict of Interests}

The authors declare that there is no conflict of interest.

\section{Ackowledgment}

WORK ATTRIBUTED TO: Academic Unit of Trauma and Orthopaedic Surgery, Clarendon Wing, Leeds General Infirmary, Great George Street, Leeds, LS1 3EX, UK.

\section{References}

[1] B. McKibbin, "The biology of fracture healing in long bones," Journal of Bone and Joint Surgery B, vol. 60, no. 2, pp. 150162, 1978.

[2] B. A. Rahn, "Direct and indirect bone healing after operative fracture treatment," Otolaryngologic Clinics of North America, vol. 20, no. 3, pp. 425-440, 1987.

[3] R. Dimitriou, E. Tsiridis, and P. V. Giannoudis, "Current concepts of molecular aspects of bone healing," Injury, vol. 36, no. 12, pp. 1392-1404, 2005.

[4] T. A. Einhorn, "The cell and molecular biology of fracture healing," Clinical Orthopaedics and Related Research, no. 355, pp. S7-S21, 1998.

[5] J. E. Puzas, R. J. O'Keefe, E. M. Schwarz, and X. Zhang, "Pharmacologic modulators of fracture healing: the role of cyclooxygenase inhibition," Journal of Musculoskeletal Neuronal Interactions, vol. 3, no. 4, pp. 308-312, 2003.

[6] Z. A. Radi and N. K. Khan, "Effects of cyclooxygenase inhibition on bone, tendon, and ligament healing," Inflammation Research, vol. 54, no. 9, pp. 358-366, 2005. 
[7] N. M. Gajraj, "The effect of cyclooxygenase-2 inhibitors on bone healing," Regional Anesthesia and Pain Medicine, vol. 28, no. 5, pp. 456-465, 2003.

[8] R. L. Cruess and J. Dumont, "Fracture healing," Canadian Journal of Surgery, vol. 18, no. 5, pp. 403-413, 1975.

[9] P. Augat, K. Margevicius, J. Simon, S. Wolf, G. Suger, and L. Claes, "Local tissue properties in bone healing: influence of size and stability of the osteotomy gap," Journal of Orthopaedic Research, vol. 16, no. 4, pp. 475-481, 1998.

[10] J. V. Vigorita, Orthopaedic Pathology, Lippincott \& Wilkins, 1st edition, 1999.

[11] F. B. Castellá, F. B. Garcia, E. M. Berry, E. B. Perello, E. Sanchez-Alepuz, and R. Gabarda, "Nonunion of the humeral shaft: long lateral butterfly fracture-a nonunion predictive pattern?" Clinical Orthopaedics and Related Research, no. 424, pp. 227-230, 2004.

[12] L. E. Claes, H. J. Wilke, P. Augat, S. Rubenacker, and K. J. Margevicius, "Effect of dynamization on gap healing of diaphyseal fractures under external fixation," Clinical Biomechanics, vol. 10, no. 5, pp. 227-234, 1995.

[13] T. Yamaji, K. Ando, S. Wolf, P. Augat, and L. Claes, "The effect of micromovement on callus formation," Journal of Orthopaedic Science, vol. 6, no. 6, pp. 571-575, 2001.

[14] S. M. Day and D. H. DeHeer, "Reversal of the detrimental effects of chronic protein malnutrition on long bone fracture healing," Journal of Orthopaedic Trauma, vol. 15, no. 1, pp. 47-53, 2001.

[15] I. Pountos, T. Georgouli, T. J. Blokhuis, H. C. Pape, and P. V. Giannoudis, "Pharmacological agents and impairment of fracture healing: what is the evidence?" Injury, vol. 39, no. 4, pp. 384-394, 2008.

[16] I. Pountos, T. Georgouli, H. Bird, G. Kontakis, and P. V. Giannoudis, "The effect of antibiotics onbone healing: current evidence," Expert Opinion on Drug Safety, vol. 10, no. 6, pp. 935-945, 2011.

[17] I. Pountos, T. Georgouli, H. Bird, and P. V. Giannoudis, "Nonsteroidal anti-inflammatory drugs: prostaglandins, indications, and side effects," International Journal of Interferon, Cytokine and Mediator Research, vol. 3, no. 1, pp. 19$27,2011$.

[18] B. F. Mcadam, F. Catella-Lawson, I. A. Mardini, S. Kapoor, J. A. Lawson, and G. A. Fitzgerald, "Systemic biosynthesis of prostacyclin by cyclooxygenase (COX)-2: the human pharmacology of a selective inhibitor of COX-2," Proceedings of the National Academy of Sciences of the United States of America, vol. 96, no. 1, pp. 272-277, 1999.

[19] T. D. Warner and J. A. Mitchell, "Cyclooxygenases: new forms, new inhibitors, and lessons from the clinic," FASEB Journal, vol. 18, no. 7, pp. 790-804, 2004.

[20] A. Whelton, "Nephrotoxicity of nonsteroidal antiinflammatory drugs: physiologic foundations and clinical implications," American Journal of Medicine, vol. 106, supplement 2, no. 5, pp. 13S-24S, 1999.

[21] M. S. Trautman, S. S. Edwin, D. Collmer, D. J. Dudley, D. Simmons, and M. D. Mitchell, "Prostaglandin H synthase2 in human gestational tissues: regulation in amnion," Placenta, vol. 17, no. 4, pp. 239-245, 1996.

[22] J. R. Vane and R. M. Botting, "Mechanism of action of nonsteroidal anti-inflammatory drugs," American Journal of Medicine, vol. 104, supplement 1, no. 3, pp. 2S-8S, 1998.

[23] J. van Ryn and M. Pairet, "Clinical experience with cyclooxygenase-2 inhibitors," Inflammation Research, vol. 48, no. 5, pp. 247-254, 1999.
[24] G. A. Green, "Understanding NSAIDs: from aspirin to COX2," Clinical Cornerstone, vol. 3, no. 5, pp. 50-58, 2001.

[25] T. D. Warner, F. Giuliano, I. Vojnovic, A. Bukasa, J. A. Mitchell, and J. R. Vane, "Nonsteroid drug selectives for cyclo-oxygenase-1 rather than cyclo-oxygenase-2 are associated with human gastrointestinal toxicity: a full in vitro analysis," Proceedings of the National Academy of Sciences of the United States of America, vol. 96, no. 13, pp. 7563-7568, 1999.

[26] P. Brooks, P. Emery, J. F. Evans et al., "Interpreting the clinical significance of the differential inhibition of cyclooxygenase-1 and cyclooxygenase-2," Rheumatology, vol. 38, no. 8, pp. 779$788,1999$.

[27] R. N. Fracon, J. M. Teófilo, R. B. Satin, and T. Lamano, "Prostaglandins and bone: potential risks and benefits related to the use of nonsteroidal anti-inflammatory drugs in clinical dentistry," Journal of Oral Science, vol. 50, no. 3, pp. 247-252, 2008.

[28] R. E. Ringel, J. I. Brenner, P. J. Haney, J. E. Burns, A. L. Moulton, and M. A. Berman, "Prostaglandin-induced periostitis: a complication of long-term PGE1 infusion in an infant with congenital heart disease," Radiology, vol. 142, no. 3, pp. 657-658, 1982.

[29] I. Suponitzky and M. Weinreb, "Differential effects of systemic prostaglandin E2 on bone mass in rat long bones and calvariae," Journal of Endocrinology, vol. 156, no. 1, pp. 51-57, 1998.

[30] W. S. Jee, K. Ueno, Y. P. Deng, and D. M. Woodbury, "The effects of prostaglandin E2 in growing rats: increased metaphyseal hard tissue and cortico-endosteal bone formation," Calcified Tissue International, vol. 37, no. 2, pp. 148-157, 1985.

[31] C. H. Lin, W. S. Jee, Y. F. Ma, and R. B. Setterberg, "Early effects of prostaglandin E2 on bone formation and resorption in different bone sites of rats," Bone, vol. 17, supplement 4, pp. 255S-259S, 1995.

[32] J. R. Nefussi and R. Baron, "PGE2 stimulates both resorption and formation of bone in vitro: differential responses of the periosteum and the endosteum in fetal rat long bone cultures," Anatomical Record, vol. 211, no. 1, pp. 9-16, 1985.

[33] H. Kawaguchi, C. C. Pilbeam, J. R. Harrison, and L. G. Raisz, "The role of prostaglandins in the regulation of bone metabolism," Clinical Orthopaedics and Related Research, no. 313, pp. 36-46, 1995.

[34] S. Dekel, G. Lenthall, and M. J. Francis, "Release of prostaglandins from bone and muscle after tibial fracture. An experimental study in rabbits," Journal of Bone and Joint Surgery B, vol. 63, no. 2, pp. 185-189, 1981.

[35] C. C. Pilbeam, P. M. Fall, C. B. Alander, and L. G. Raisz, "Differential effects of nonsteroidal anti-inflammatory drugs on constitutive and inducible prostaglandin $\mathrm{G} / \mathrm{H}$ synthase in cultured bone cells," Journal of Bone and Mineral Research, vol. 12, no. 8, pp. 1198-1203, 1997.

[36] X. Zhang, E. M. Schwarz, D. A. Young, J. E. Puzas, R. N. Rosier, and R. J. O'Keefe, “Cyclooxygenase-2 regulates mesenchymal cell differentiation into the osteoblast lineage and is critically involved in bone repair," Journal of Clinical Investigation, vol. 109, no. 11, pp. 1405-1415, 2002.

[37] L. C. Gerstenfeld and T. A. Einhorn, "COX inhibitors and their effects on bone healing," Expert Opinion on Drug Safety, vol. 3, no. 2, pp. 131-136, 2004.

[38] T. Arikawa, K. Omura, and I. Morita, "Regulation of bone morphogenetic protein-2 expression by endogenous 
prostaglandin E2 in human mesenchymal stem cells," Journal of Cellular Physiology, vol. 200, no. 3, pp. 400-406, 2004.

[39] S. Jurado, N. Garcia-Giralt, A. Díez-Pérez et al., "Effect of IL-1 $\beta$, PGE2, and TGF- $\beta 1$ on the expression of OPG and RANKL in normal and osteoporotic primary human osteoblasts," Journal of Cellular Biochemistry, vol. 110, no. 2, pp. 304-310, 2010.

[40] V. M. Paralkar, W. A. Grasser, A. L. Mansolf et al., "Regulation of BMP-7 expression by retinoic acid and prostaglandin E(2)," Journal of Cellular Physiology, vol. 190, no. 2, pp. 207217, 2002.

[41] M. Coetzee, M. Haag, A. M. Joubert, and M. C. Kruger, "Effects of arachidonic acid, docosahexaenoic acid and prostaglandin $\mathrm{E}(2)$ on cell proliferation and morphology of MG-63 and MC3T3-E1 osteoblast-like cells," Prostaglandins Leukotrienes and Essential Fatty Acids, vol. 76, no. 1, pp. 3545, 2007.

[42] M. Machwate, S. B. Rodan, G. A. Rodan, and S. I. Harada, "Sphingosine kinase mediates cyclic AMP suppression of apoptosis in rat periosteal cells," Molecular Pharmacology, vol. 54, no. 1, pp. 70-77, 1998.

[43] M. Machwate, S. Harada, C. T. Leu et al., "Prostaglandin receptor $\mathrm{EP}(4)$ mediates the bone anabolic effects of PGE(2)," Molecular Pharmacology, vol. 60, no. 1, pp. 36-41, 2001.

[44] M. Zhang, H. C. Ho, T. J. Sheu et al., "EP1(-/-) mice have enhanced osteoblast differentiation and accelerated fracture repair," Journal of Bone and Mineral Research, vol. 26, no. 4, pp. 792-802, 2011.

[45] A. Beck, K. Salem, G. Krischak, L. Kinzl, M. Bischoff, and A. Schmelz, "Nonsteroidal anti-inflammatory drugs (NSAIDs) in the perioperative phase in traumatology and orthopedics. Effects on bone healing," Operative Orthopadie und Traumatologie, vol. 17, no. 6, pp. 569-578, 2005.

[46] A. Holdgate and T. Pollock, "Systematic review of the relative efficacy of non-steroidal anti-inflammatory drugs and opioids in the treatment of acute renal colic," British Medical Journal, vol. 328, no. 7453, pp. 1401-1404, 2004.

[47] D. G. Monzón, J. Vazquez, J. R. Jauregui, and K. V. Iserson, "Pain treatment in post-traumatic hip fracture in the elderly: regional block vs. systemic non-steroidal analgesics," International Journal of Emergency Medicine, vol. 3, no. 4, pp. 321-325, 2010.

[48] G. Stacher, H. Steinringer, and S. Schneider, "Experimental pain induced by electrical and thermal stimulation of the skin in healthy man: sensitivity to 75 and $150 \mathrm{mg}$ diclofenac sodium in comparison with $60 \mathrm{mg}$ codeine and placebo," British Journal of Clinical Pharmacology, vol. 21, no. 1, pp. 35-43, 1986.

[49] T. Kantor, M. B. Cavaliere, M. Hopper, and S. Roepke, "A double-blind parallel comparison of ketoprofen, codeine, and placebo in patients with moderate to severe postpartum pain," Journal of Clinical Pharmacology, vol. 24, no. 5-6, pp. 228-234, 1984.

[50] M. H. Ebell, "NSAIDs vs. opiates for pain in acute renal colic," American Family Physician, vol. 70, no. 9, p. 1682, 2004.

[51] F. Camu, T. Beecher, D. P. Recker, and K. M. Verburg, "Valdecoxib, a COX-2-specific inhibitor, is an efficacious, opioidsparing analgesic in patients undergoing hip arthroplasty," American Journal of Therapeutics, vol. 9, no. 1, pp. 43-51, 2002.

[52] D. M. Turner, J. S. Warson, T. C. Wirt, R. D. Scalley, R. S. Cochran, and K. J. Miller, "The use of ketorolac in lumbar spine surgery: a cost-benefit analysis," Journal of Spinal Disorders, vol. 8, no. 3, pp. 206-212, 1995.

[53] W. M. O’Neill, G. W. Hanks, P. Simpson, M. T. Fallon, E. Jenkins, and K. Wesnes, "The cognitive and psychomotor effects of morphine in healthy subjects: a randomized controlled trial of repeated (four) oral doses of dextropropoxyphene, morphine, lorazepam and placebo," Pain, vol. 85, no. 1-2, pp. 209-215, 2000.

[54] E. Marret, N. Elia, J. B. Dahl et al., "Susceptibility to fraud in systematic reviews: lessons from the reuben case," Anesthesiology, vol. 111, no. 6, pp. 1279-1289, 2009.

[55] H. L. Rittner, P. Kranke, M. Schäfer, N. Roewer, and A. Brack, "What can we learn from the Scott Reuben case? scientific misconduct in anaesthesiology," Anaesthesist, vol. 58, no. 12, pp. 1199-1209, 2009.

[56] H. Törnkvist, B. R. Danielsson, L. Dencker, and O. S. Nilsson, "Lack of effect of indomethacin on mesenchymal limb-bud cells in vitro," Acta Orthopaedica Scandinavica, vol. 55, no. 3, pp. 378-380, 1984.

[57] M. L. Ho, J. K. Chang, L. Y. Chuang, H. K. Hsu, and G. J. Wang, "Effects of nonsteroidal anti-inflammatory drugs and prostaglandins on osteoblastic functions," Biochemical Pharmacology, vol. 58, no. 6, pp. 983-990, 1999.

[58] C. E. Evans and C. Butcher, "The influence on human osteoblasts in vitro on non-steroidal anti-inflammatory drugs which act on different cyclooxygenase enzymes," Journal of Bone and Joint Surgery B, vol. 86, no. 3, pp. 444449, 2004.

[59] J. L. Wang, K. L. Lin, J. S. Chen et al., "Effect of celecoxib on $\mathrm{Ca}^{2+}$ movement and cell proliferation in human osteoblasts," Biochemical Pharmacology, vol. 67, no. 6, pp. 1123-1130, 2004.

[60] J. K. Chang, G. J. Wang, S. T. Tsai, and M. L. Ho, "Nonsteroidal anti-inflammatory drug effects on osteoblastic cell cycle, cytotoxicity, and cell death," Connective Tissue Research, vol. 46, no. 4-5, pp. 200-210, 2005.

[61] Y. Wang, X. Chen, W. Zhu, H. Zhang, S. Hu, and X. Cong, "Growth inhibition of mesenchymal stem cells by aspirin: involvement of the wnt/ $\beta$-catenin signal pathway," Clinical and Experimental Pharmacology and Physiology, vol. 33, no. 8, pp. 696-701, 2006.

[62] M. Wiontzek, G. Matziolis, S. Schuchmann et al., "Effects of dexamethasone and celecoxib on calcium homeostasis and expression of cyclooxygenase-2 mRNA in MG-63 human osteosarcoma cells," Clinical and Experimental Rheumatology, vol. 24, no. 4, pp. 366-372, 2006.

[63] B. Wolfesberger, C. Hoelzl, I. Walter et al., "In vitro effects of meloxicam with or without doxorubicin on canine osteosarcoma cells," Journal of Veterinary Pharmacology and Therapeutics, vol. 29, no. 1, pp. 15-23, 2006.

[64] J. K. Chang, C. J. Li, S. C. Wu et al., "Effects of antiinflammatory drugs on proliferation, cytotoxicity and osteogenesis in bone marrow mesenchymal stem cells," Biochemical Pharmacology, vol. 74, no. 9, pp. 1371-1382, 2007.

[65] M. Kellinsalmi, V. Parikka, J. Risteli et al., "Inhibition of cyclooxygenase-2 down-regulates osteoclast and osteoblast differentiation and favours adipocyte formation in vitro," European Journal of Pharmacology, vol. 572, no. 2-3, pp. 102110, 2007.

[66] P. Arpornmaeklong, B. Akarawatcharangura, P. Pripatnanont, S. H. Lee, and C. Ohkubo, "Factors influencing effects of specific COX-2 inhibitor NSAIDs on growth and differentiation of mouse osteoblasts on titanium surfaces," 
International Journal of Oral and Maxillofacial Implants, vol. 23, no. 6, pp. 1071-1081, 2008.

[67] H. Abukawa, M. Phelps, P. Jackson et al., "Effect of ibuprofen on osteoblast differentiation of porcine bone marrowderived progenitor cells," Journal of Oral and Maxillofacial Surgery, vol. 67, no. 11, pp. 2412-2417, 2009.

[68] J. K. Chang, C. J. Li, H. J. Liao, C. K. Wang, G. J. Wang, and M. L. Ho, "Anti-inflammatory drugs suppress proliferation and induce apoptosis through altering expressions of cell cycle regulators and pro-apoptotic factors in cultured human osteoblasts," Toxicology, vol. 258, no. 2-3, pp. 148-156, 2009.

[69] P. Kolar, S. Lach, T. Gaber et al., "Effects of celecoxib on the expression of osteoprotegerin, energy metabolism and cell viability in cultured human osteoblastic cells," Clinical and Experimental Rheumatology, vol. 27, no. 1, pp. 99-107, 2009.

[70] D. S. Yoon, J. H. Yoo, Y. H. Kim, S. Paik, C. D. Han, and J. W. Lee, "The effects of COX-2 inhibitor during osteogenic differentiation of bone marrow-derived human mesenchymal stem cells," Stem Cells and Development, vol. 19, no. 10, pp. 1523-1533, 2010.

[71] L. D. A. R. Guez, O. G. A. M. Nez, M. Arroyo-Morales, L. R. Guez-Pérez, B. Rubio-Ruiz, and C. Ruiz, "Effects of indomethacin, nimesulide, and diclofenac on human MG-63 osteosarcoma cell line," Biological Research For Nursing. In press.

[72] M. Müller, O. Raabe, K. Addicks, S. Wenisch, and S. Arnhold, "Effects of non-steroidal anti-inflammatory drugs on proliferation, differentiation and migration in equine mesenchymal stem cells," Cell Biology International, vol. 35, no. 3, pp. 235-248, 2011.

[73] I. Pountos, P. V. Giannoudis, E. Jones et al., "NSAIDS inhibit in vitro MSC chondrogenesis but not osteogenesis: implications for mechanism of bone formation inhibition in man," Journal of Cellular and Molecular Medicine, vol. 15, no. 3, pp. 525-534, 2011.

[74] L. C. Gerstenfeld, M. Thiede, K. Siebert et al., "Differential inhibition of fracture healing by non-selective and cyclooxygenase-2 selective non-steroidal anti-inflammatory drugs," Journal of Orthopaedic Research, vol. 21, no. 4, pp. 670-675, 2003.

[75] G. J. Martin Jr., S. D. Boden, and L. Titus, "Recombinant human bone morphogenetic protein-2 overcomes the inhibitory effect of ketorolac, a nonsteroidal antiinflammatory drug (NSAID), on posterolateral lumbar intertransverse process spine fusion," Spine, vol. 24 , no. 21, pp. 2188-2193, 1999.

[76] M. L. Ho, J. K. Chang, and G. J. Wang, "Effects of ketorolac on bone repair: a radiographic study in modeled demineralized bone matrix grafted rabbits," Pharmacology, vol. 57, no. 3, pp. 148-159, 1998.

[77] M. V. Martins, M. A. da Silva, E. Medici Filho, L. C. de Moraes, J. C. D. M. Castilho, and R. F. da Rocha, "Evaluation of digital optical density of bone repair in rats medicated with ketoprofen," Brazilian Dental Journal, vol. 16, no. 3, pp. 207212, 2005.

[78] O. Reikeraas and L. Engebretsen, "Effects of ketoralac tromethamine and indomethacin on primary and secondary bone healing. An experimental study in rats," Archives of Orthopaedic and Trauma Surgery, vol. 118, no. 1-2, pp. 5052, 1998.

[79] K. D. Riew, J. Long, J. Rhee et al., "Time-dependent inhibitory effects of indomethacin on spinal fusion," Journal of Bone and Joint Surgery A, vol. 85, no. 4, pp. 632-634, 2003.
[80] K. M. Brown, M. M. Saunders, T. Kirsch, H. J. Donahue, and J. S. Reid, "Effect of COX-2-specific inhibition on fracturehealing in the rat femur," Journal of Bone and Joint Surgery A, vol. 86, no. 1, pp. 116-123, 2004.

[81] P. E. Persson, G. Sisask, and O. Nilsson, "Indomethacin inhibits bone formation in inductive allografts but not in autografts: studies in rat," Acta Orthopaedica, vol. 76, no. 4, pp. 465-469, 2005.

[82] E. Sudmann and G. Bang, "Indomethacin-induced inhibition of haversian remodelling in rabbits," Acta Orthopaedica Scandinavica, vol. 50, no. 6, pp. 621-627, 1979.

[83] J. R. Dimar II, W. A. Ante, Y. P. Zhang, and S. D. Glassman, "The effects of nonsteroidal anti-inflammatory drugs on posterior spinal fusions in the rat," Spine, vol. 21, no. 16, pp. 1870-1876, 1996.

[84] H. L. Allen, A. Wase, and W. T. Bear, "Indomethacin and aspirin: effect of nonsteroidal anti-inflammatory agents on the rate of fracture repair in the rat," Acta Orthopaedica Scandinavica, vol. 51, no. 4, pp. 595-600, 1980.

[85] T. Karachalios, L. Boursinos, L. Poultsides, L. Khaldi, and K. N. Malizos, "The effects of the short-term administration of low therapeutic doses of anti-COX-2 agents on the healing of fractures: an experimental study in rabbits," Journal of Bone and Joint Surgery B, vol. 89, no. 9, pp. 1253-1260, 2007.

[86] J. Keller, C. Bünger, T. T. Andreassen, B. Bak, and U. Lucht, "Bone repair inhibited by indomethacin. Effects on bone metabolism and strength of rabbit osteotomies," Acta Orthopaedica Scandinavica, vol. 58, no. 4, pp. 379-383, 1987.

[87] J. Keller, I. Bayer-Kristensen, B. Bak et al., "Indomethacin and bone remodeling. Effect on cortical bone after osteotomy in rabbits," Acta Orthopaedica Scandinavica, vol. 60, no. 1, pp. 119-121, 1989.

[88] H. Törnkvist, T. S. Lindholm, P. Netz, L. Strömberg, and T. C. Lindholm, "Effect of ibuprofen and indomethacin on bone metabolism reflected in bone strength," Clinical Orthopaedics and Related Research, vol. 187, pp. 255-259, 1984.

[89] H. E. Høgevold, B. Grøgaard, and O. Reikerås, "Effects of short-term treatment with corticosteroids and indomethacin on bone healing. A mechanical study of osteotomies in rats," Acta Orthopaedica Scandinavica, vol. 63, no. 6, pp. 607-611, 1992.

[90] L. B. Engesaeter, B. Sudmann, and E. Sudmann, "Fracture healing in rats inhibited by locally administered indomethacin," Acta Orthopaedica Scandinavica, vol. 63, no. 3, pp. 330-333, 1992.

[91] S. Sato, T. Kim, T. Arai, S. Maruyama, M. Tajima, and N. Utsumi, "Comparison between the effects of dexamethasone and indomethacin on bone wound healing," Japanese Journal of Pharmacology, vol. 42, no. 1, pp. 71-78, 1986.

[92] S. Goodman, T. Ma, M. Trindade et al., "COX-2 selective NSAID decreases bone ingrowth in vivo," Journal of Orthopaedic Research, vol. 20, no. 6, pp. 1164-1169, 2002.

[93] M. A. Kaygusuz, C. C. Turan, N. E. Aydin et al., "The effects of G-CSF and naproxen sodium on the serum TGF- $\beta 1$ level and fracture healing in rat tibias," Life Sciences, vol. 80, no. 1, pp. 67-73, 2006.

[94] S. M. Leonelli, B. A. Goldberg, J. Safanda, M. R. Bagwe, S. Sethuratnam, and S. J. King, "Effects of a cyclooxygenase-2 inhibitor (rofecoxib) on bone healing," American Journal of Orthopedics, vol. 35, no. 2, pp. 79-84, 2006.

[95] J. P. O’Connor, J. T. Capo, V. Tan et al., "A comparison of the effects of ibuprofen and rofecoxib on rabbit fibula osteotomy healing," Acta Orthopaedica, vol. 80, no. 5, pp. 597-605, 2009. 
[96] G. Obeid, X. Zhang, X. Wang, and M. Jeffcoat, "Effect of ibuprofen on the healing and remodeling of bone and articular cartilage in the rabbit temporomandibular joint," Journal of Oral and Maxillofacial Surgery, vol. 50, no. 8, pp. 843-859, 1992.

[97] A. Beck, G. Krischak, T. Sorg et al., "Influence of diclofenac (group of nonsteroidal anti-inflammatory drugs) on fracture healing," Archives of Orthopaedic and Trauma Surgery, vol. 123, no. 7, pp. 327-332, 2003.

[98] G. D. Krischak, P. Augat, T. Sorg et al., "Effects of diclofenac on periosteal callus maturation in osteotomy healing in an animal model," Archives of Orthopaedic and Trauma Surgery, vol. 127, no. 1, pp. 3-9, 2007.

[99] C. Sen, M. Erdem, T. Gunes, D. Koseoglu, and N. O. Filiz, "Effects of diclofenac and tenoxicam on distraction osteogenesis," Archives of Orthopaedic and Trauma Surgery, vol. 127, no. 3, pp. 153-159, 2007.

[100] V. Giordano, M. Giordano, I. G. Knackfuss, M. I. Apfel, and R. D. Gomes, "Effect of tenoxicam on fracture healing in rat tibiae," Injury, vol. 34, no. 2, pp. 85-94, 2003.

[101] A. M. Simon and J. P. O'Connor, "Dose and time-dependent effects of cyclooxygenase-2 inhibition on fracture-healing," Journal of Bone and Joint Surgery A, vol. 89, no. 3, pp. 500$511,2007$.

[102] M. Bergenstock, W. Min, A. M. Simon, C. Sabatino, and J. P. O'Connor, "A comparison between the effects of acetaminophen and celecoxib on bone fracture healing in rats," Journal of Orthopaedic Trauma, vol. 19, no. 10, pp. 717723, 2005.

[103] F. V. Ribeiro, J. B. César-Neto, F. H. Nociti Jr et al., "Selective cyclooxygenase-2 inhibitor may impair bone healing around titanium implants in rats," Journal of Periodontology, vol. 77, no. 10, pp. 1731-1735, 2006.

[104] K. Endo, K. Sairyo, S. Komatsubara et al., "Cyclooxygenase-2 inhibitor inhibits the fracture healing," Journal of Physiological Anthropology and Applied Human Science, vol. 21, no. 5, pp. 235-238, 2002.

[105] K. Endo, K. Sairyo, S. Komatsubara et al., "Cyclooxygenase-2 inhibitor delays fracture healing in rats," Acta Orthopaedica, vol. 76, no. 4, pp. 470-474, 2005.

[106] S. E. Utvåg, O. M. Fuskevåg, H. Shegarfi, and O. Reikerås, "Short-term treatment with COX-2 inhibitors does not impair fracture healing," Journal of Investigative Surgery, vol. 23 , no. 5 , pp. 257-261, 2010.

[107] L. C. Gerstenfeld, M. Al-Ghawas, Y. M. Alkhiary et al., "Selective and nonselective cyclooxygenase-2 inhibitors and experimental frature-healing: reversibility of effects after short-term treatment," Journal of Bone and Joint Surgery A, vol. 89, no. 1, pp. 114-125, 2007.

[108] S. B. Goodman, T. Ma, L. Mitsunaga, K. Miyanishi, M. C. Genovese, and R. L. Smith, "Temporal effects of a COX-2selective NSAID on bone ingrowth," Journal of Biomedical Materials Research A, vol. 72, no. 3, pp. 279-287, 2005.

[109] M. Murnaghan, G. Li, and D. R. Marsh, "Nonsteroidal antiinflammatory drug-induced fracture nonunion: an inhibition of angiogenesis?" Journal of Bone and Joint Surgery A, vol. 88, supplement 3, pp. S140-S147, 2006.

[110] R. N. Fracon, J. M. Teófilo, L. C. Moris, and T. Lamano, "Treatment with paracetamol, ketorolac or etoricoxib did not hinder alveolar bone healing: a histometric study in rats," Journal of Applied Oral Science, vol. 18, no. 6, pp. 630-634, 2010.

[111] B. H. Mullis, S. T. Copland, P. S. Weinhold, T. Miclau, G. E. Lester, and G. D. Bos, "Effect of COX-2 inhibitors and non-steroidal anti-inflammatory drugs on a mouse fracture model," Injury, vol. 37, no. 9, pp. 827-837, 2006.

[112] J. Urrutia, R. Mardones, and F. Quezada, "The effect of ketoprophen on lumbar spinal fusion healing in a rabbit model. Laboratory investigation," Journal of Neurosurgery: Spine, vol. 7, no. 6, pp. 631-636, 2007.

[113] H. J. van der Heide, G. Hannink, P. Buma, and B. W. Schreurs, "No effect of ketoprofen and meloxicam on bone graft ingrowth: a bone chamber study in goats," Acta Orthopaedica, vol. 79, no. 4, pp. 548-554, 2008.

[114] M. W. Elves, I. Bayley, and P. J. Roylance, "The effect of Indomethacin upon experimental fractures in the rat," Acta Orthopaedica Scandinavica, vol. 53, no. 1, pp. 35-41, 1982.

[115] J. Keller, P. Kjaersgaard-Andersen, I. Bayer-Kristensen, and F. Melsen, "Indomethacin and bone trauma. Effects on remodelling of rabbit bone," Acta Orthopaedica Scandinavica, vol. 61, no. 1, pp. 66-69, 1990.

[116] I. Boiskin, S. Epstein, F. Ismail, M. D. Fallon, and W. Levy, "Long term administration of prostaglandin inhibitors in vivo fail to influence cartilage and bone mineral metabolism in the rat," Bone and Mineral, vol. 4, no. 1, pp. 27-36, 1988.

[117] S. W. Mbugua, L. A. Skoglund, and P. Løkken, "Effects of phenylbutazone and indomethacin on the post-operative course following experimental orthopaedic surgery in dogs," Acta veterinaria Scandinavica, vol. 30, no. 1, pp. 27-35, 1989.

[118] E. Sudmann, T. Tveita, and J. Hald Jr. Jr, "Lack of effect of indomethacin on ordered growth of the femur in rats," Acta Orthopaedica Scandinavica, vol. 53, no. 1, pp. 43-49, 1982.

[119] J. Long, S. Lewis, T. Kuklo, Y. Zhu, and K. D. Riew, "The effect of cyclooxygenase-2 inhibitors on spinal fusion," Journal of Bone and Joint Surgery, vol. 84, no. 10, pp. 1763-1768, 2002.

[120] B. Mullis, S. Copeland, P. Weinhold et al., "Effect of COX2 inhibitors and NSAIDs on fracture healing in a mouse model," Transactions of the Annual Meeting-Orthopaedic Research Society, vol. 27, p. 712, 2002.

[121] H. Törnkvist and T. S. Lindholm, "Effect of ibuprofen on mass and composition of fracture callus and bone. An experimental study on adult rat," Scandinavian Journal of Rheumatology, vol. 9, no. 3, pp. 167-171, 1980.

[122] M. H. Huo, N. W. Troiano, R. R. Pelker, C. M. Gundberg, and G. E. Friedlaender, "The influence of Ibuprofen on fracture repair: biomechanical, biochemical, histologic, and histomorphometric parameters in rats," Journal of Orthopaedic Research, vol. 9, no. 3, pp. 383-390, 1991.

[123] B. C. Tiseo, G. N. Namur, E. J. de Paula, R. M. Junior, and C. R. de Oliveira, "Experimental study of the action of COX-2 selective nonsteroidal anti-inflammatory drugs and traditional anti-inflammatory drugs in bone regeneration," Clinics, vol. 61, no. 3, pp. 223-230, 2006.

[124] J. M. Teófilo, G. S. Giovanini, R. N. Fracon, and T. Lamano, "Histometric study of alveolar bone healing in rats treated with the nonsteroidal anti-inflammatory drug nimesulide," Implant Dentistry, vol. 20, no. 2, pp. e7-e13, 2011.

[125] D. J. Hak, K. S. Schulz, B. Khoie, and S. J. Hazelwood, “The effect of Cox-2 specific inhibition on direct fracture healing in the rabbit tibia," Journal of Orthopaedic Science, vol. 16, no. 1, pp. 93-98, 2011.

[126] H. Nyangoga, E. Aguado, E. Goyenvalle, M. F. Baslé, and D. Chappard, "A non-steroidal anti-inflammatory drug (ketoprofen) does not delay $\beta$-TCP bone graft healing," Acta Biomaterialia, vol. 6, no. 8, pp. 3310-3317, 2010.

[127] R. D. Altman, L. L. Latta, R. Keer, K. Renfree, F. J. Hornicek, and K. Banovac, "Effect of nonsteroidal antiinflammatory 
drugs on fracture healing: a laboratory study in rats," Journal of Orthopaedic Trauma, vol. 9, no. 5, pp. 392-400, 1995.

[128] M. Deguchi, A. J. Rapoff, and T. A. Zdeblick, "Posterolateral fusion for isthmic spondylolisthesis in adults: analysis of fusion rate and clinical results," Journal of Spinal Disorders, vol. 11, no. 6, pp. 459-464, 1998.

[129] S. D. Glassman, S. M. Rose, J. R. Dimar, R. M. Puno, M. J. Campbell, and J. R. Johnson, "The effect of postoperative nonsteroidal anti-inflammatory drug administration on spinal fusion," Spine, vol. 23, no. 7, pp. 834-838, 1998.

[130] M. G. Vitale, J. C. Choe, M. W. Hwang et al., "Use of ketorolac tromethamine in children undergoing scoliosis surgery: an analysis of complications," Spine Journal, vol. 3, no. 1, pp. 5562, 2003.

[131] S. Y. Park, S. H. Moon, M. S. Park, K. S. Oh, and H. M. Lee, "The effects of ketorolac injected via patient controlled analgesia postoperatively on spinal fusion," Yonsei Medical Journal, vol. 46, no. 2, pp. 245-251, 2005.

[132] B. B. Pradhan, R. L. Tatsumi, J. Gallina, C. A. Kuhns, J. C. Wang, and E. G. Dawson, "Ketorolac and spinal fusion: does the perioperative use of ketorolac really inhibit spinal fusion?" Spine, vol. 33, no. 19, pp. 2079-2082, 2008.

[133] D. J. Sucato, J. F. Lovejoy, S. Agrawal, E. Elerson, T. Nelson, and A. McClung, "Postoperative ketorolac does not predispose to pseudoarthrosis following posterior spinal fusion and instrumentation for adolescent idiopathic scoliosis," Spine, vol. 33, no. 10, pp. 1119-1124, 2008.

[134] J. M. Lumawig, A. Yamazaki, and K. Watanabe, "Dosedependent inhibition of diclofenac sodium on posterior lumbar interbody fusion rates," Spine Journal, vol. 9, no. 5, pp. 343-349, 2009.

[135] P. L. Horn, S. Wrona, A. C. Beebe, and J. E. Klamar, "A retrospective quality improvement study of ketorolac use following spinal fusion in pediatric patients," Orthopaedic Nursing, vol. 29, no. 5, pp. 342-343, 2010.

[136] T. R. Davis and C. E. Ackroyd, "Non-steroidal antiinflammatory agents in the management of Colles' fractures," British Journal of Clinical Practice, vol. 42, no. 5, pp. 184-189, 1988.

[137] P. Adolphson, H. Abbaszadegan, U. Jonsson, N. Dalen, H. E. Sjoberg, and S. Kalen, "No effects of piroxicam on osteopenia and recovery after Colles' fracture. A randomized, double-blind, placebo-controlled, prospective trial," Archives of Orthopaedic and Trauma Surgery, vol. 112, no. 3, pp. 127130, 1993.

[138] C. K. Butcher and D. R. Marsh, "Non-steroidal antiinflammatory drugs delay tibial fracture union," Injury, vol. 27, no. 5, p. 375, 1996.

[139] C. Wurnig, E. Schwameis, P. Bitzan, and F. Kainberger, "Six-year results of a cementless stem with prophylaxis against heterotopic bone," Clinical Orthopaedics and Related Research, no. 361, pp. 150-158, 1999.

[140] P. V. Giannoudis, D. A. MacDonald, S. J. Matthews, R. M. Smith, A. J. Furlong, and P. de Boer, "Nonunion of the femoral diaphysis. The influence of reaming and nonsteroidal anti-inflammatory drugs," Journal of Bone and Joint Surgery, vol. 82, no. 5, pp. 655-658, 2000.

[141] M. Bhandari, P. Tornetta III, S. Sprague et al., "Predictors of reoperation following operative management of fractures of the tibial shaft," Journal of Orthopaedic Trauma, vol. 17, no. 5, pp. 353-361, 2003.

[142] T. A. Burd, M. S. Hughes, and J. O. Anglen, "Heterotopic ossification prophylaxis with indomethacin increases the risk of long-bone nonunion," Journal of Bone and Joint Surgery, vol. 85, no. 5, pp. 700-705, 2003.

[143] A. Sculean, M. Berakdar, N. Donos, T. M. Auschill, and N. B. Arweiler, "The effect of postsurgical administration of a selective cyclo-oxygenase-2 inhibitor on the healing of intrabony defects following treatment with enamel matrix proteins," Clinical Oral Investigations, vol. 7, no. 2, pp. 108$112,2003$.

[144] T. Bhattacharyya, R. Levin, M. S. Vrahas, and D. H. Solomon, "Nonsteroidal antiinflammatory drugs and nonunion of humeral shaft fractures," Arthritis Care and Research, vol. 53, no. 3, pp. 364-367, 2005.

[145] A. Meunier, P. Aspenberg, and L. Good, “Celecoxib does not appear to affect prosthesis fixation in total knee replacement: a randomized study using radiostereometry in 50 patients," Acta Orthopaedica, vol. 80, no. 1, pp. 46-50, 2009.

[146] J. Aerssens, S. Boonen, G. Lowet, and J. Dequeker, "Interspecies differences in bone composition, density, and quality: potential implications for in vivo bone research," Endocrinology, vol. 139, no. 2, pp. 663-670, 1998.

[147] S. Miyatake, H. Ichiyama, E. Kondo, and K. Yasuda, "Randomized clinical comparisons of diclofenac concentration in the soft tissues and blood plasma between topical and oral applications," British Journal of Clinical Pharmacology, vol. 67, no. 1, pp. 125-129, 2009.

[148] A. Rahal, A. Kumar, A. H. Ahmad, and J. K. Malik, "Pharmacokinetics of diclofenac and its interaction with enrofloxacin in sheep," Research in Veterinary Science, vol. 84, no. 3, pp. 452-456, 2008.

[149] I. Pountos, T. Georgouli, and P. V. Giannoudis, "The effect of autologous serum obtained after fracture on the proliferation and osteogenic differentiation of mesenchymal stem cells," Cellular and Molecular Biology, vol. 54, no. 1, pp. 33-39, 2008.

[150] I. Pountos, T. Georgouli, S. Perry, J. Morley, and P. Giannoudis, "Systemic signals after fracture: their effect in osteogenesis," Injury Extra, vol. 38, pp. 161-162, 2007.

[151] P. M. Arnold and J. A. Klemp, "Assessment of malunion in spinal fusion,” Neurosurgery Quarterly, vol. 15, no. 4, pp. 239247, 2005.

[152] M. Fransen and B. Neal, "Non-steroidal anti-inflammatory drugs for preventing heterotopic bone formation after hip arthroplasty," Cochrane Database of Systematic Reviews, no. 3, Article ID CD001160, 2004.

[153] E. F. McCarthy and M. Sundaram, "Heterotopic ossification: a review," Skeletal Radiology, vol. 34, no. 10, pp. 609-619, 2005.

[154] L. V. Bossche and G. Vanderstraeten, "Heterotopic ossification: a review," Journal of Rehabilitation Medicine, vol. 37, no. 3, pp. 129-136, 2005.

[155] L. Song and R. S. Tuan, "Transdifferentiation potential of human mesenchymal stem cells derived from bone marrow," FASEB Journal, vol. 18, no. 9, pp. 980-982, 2004.

[156] L. E. Dahners and B. H. Mullis, "Effects of nonsteroidal anti-inflammatory drugs on bone formation and soft-tissue healing," The Journal of the American Academy of Orthopaedic Surgeons, vol. 12, no. 3, pp. 139-143, 2004. 


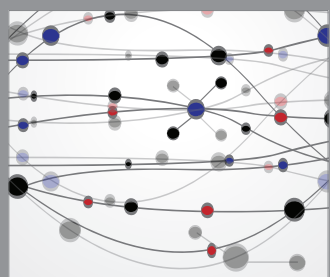

The Scientific World Journal
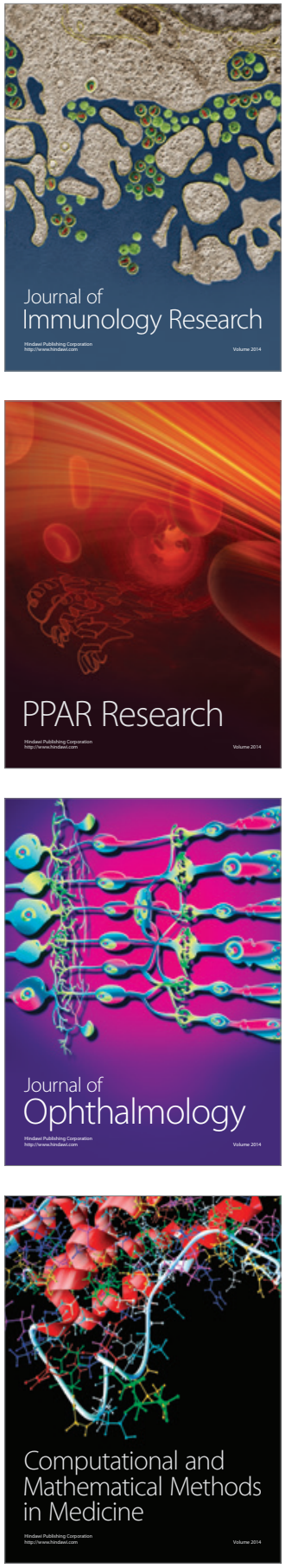

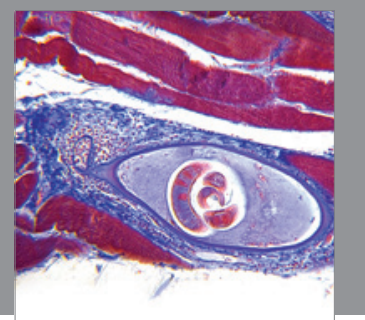

Gastroenterology

Research and Practice
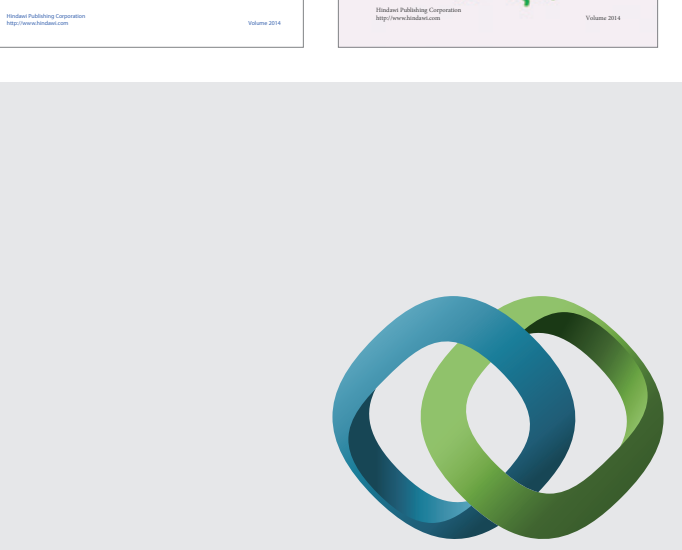

\section{Hindawi}

Submit your manuscripts at

http://www.hindawi.com
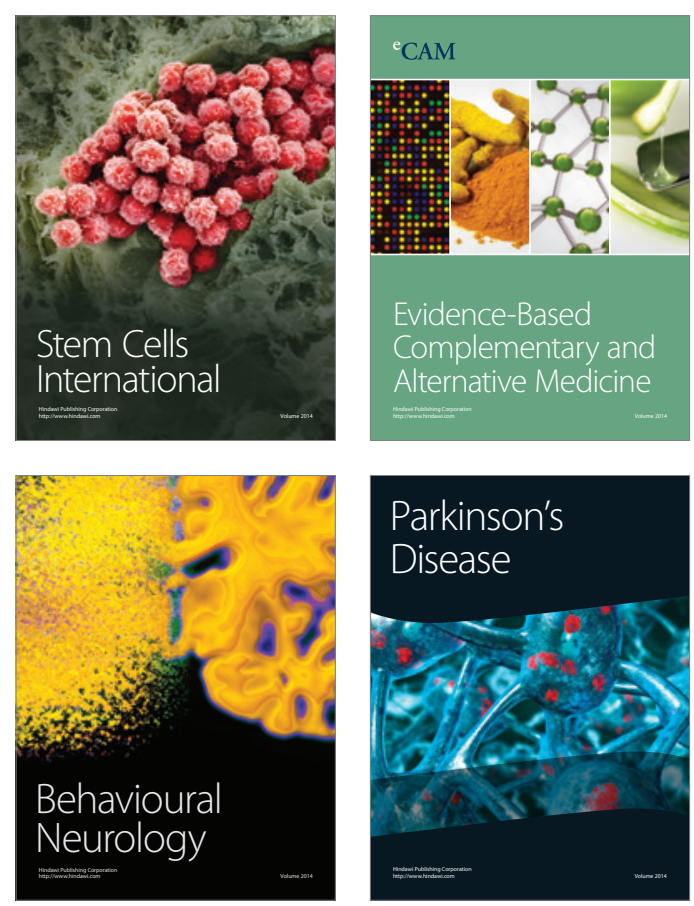

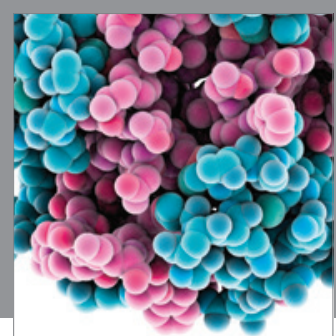

Journal of
Diabetes Research

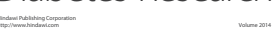

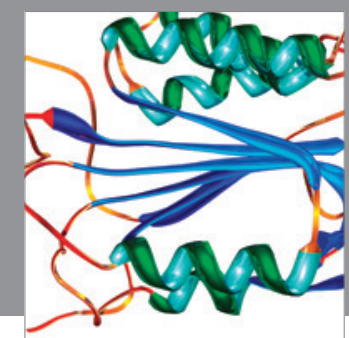

Disease Markers
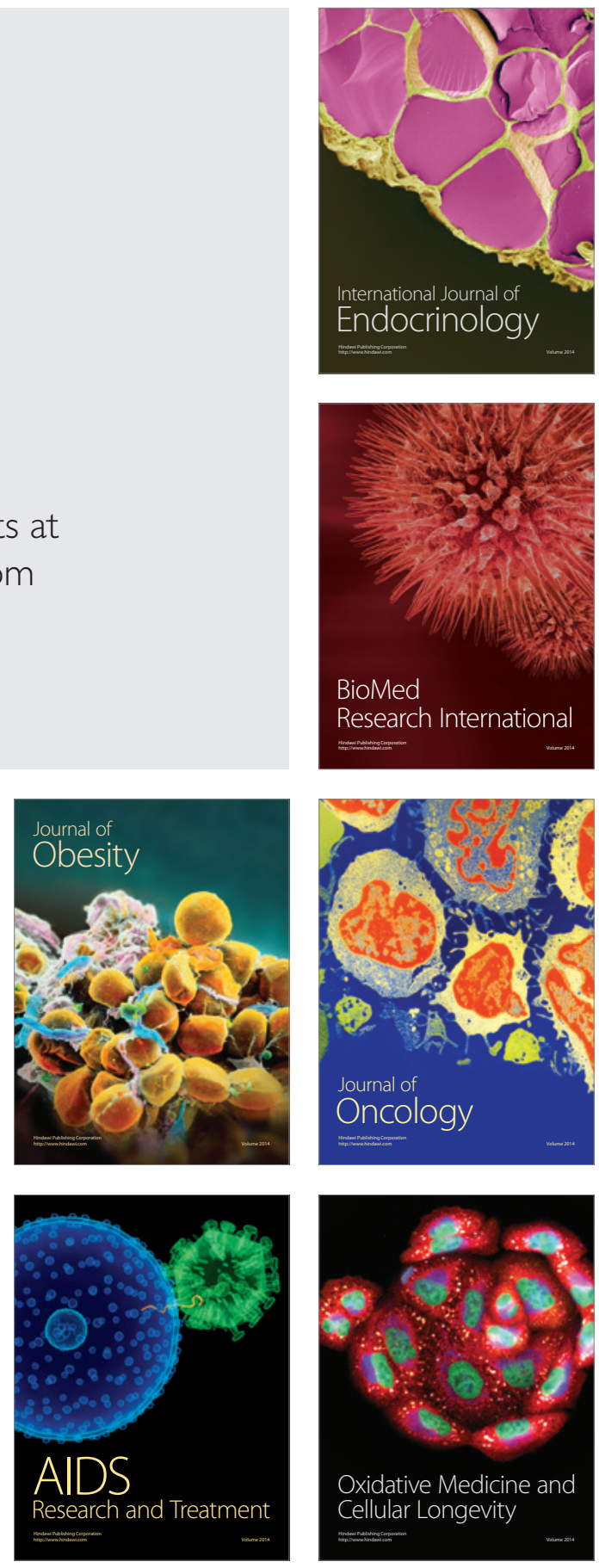